\title{
Üçüncü Sınıf Öğrencilerinin Okuma Becerilerine Göre Problem Çözme Başarıları ve Çözüm Sürecinde Karşılaştıkları Güiçlükler
}

\author{
DOI: 10.26466/opus.639152
}

\author{
Dilek Sezgin Memnun* - Nezaket İlksen Kanbur** \\ * Doç. Dr, Bursa Uludağ Üniversitesi, Eğitim Fakültesi, Görükle / Bursa / Türkiye \\ E-Posta: dilekmemnun@gmail.com ORCID: 0000-0003-3254-8858 \\ ** Milli Eğitim Bakanlığı, Sınıf Öğretmeni / Kocaeli/ Türkiye \\ E-Posta : nezaketsu@gmail.com \\ ORCID: $\underline{0000-0002-0482-2146}$
}

\begin{abstract}
Öz
Bu araştırmada, ilkokul üçüncü sını öğrencilerinin okuma becerilerine göre problem çözme başarıları ile problem çözme sürecinde yaşadıkları güçlüklerin incelenmesi amaçlanmıştır. Katılımcıların okuma becerilerine ilişkin veriler, toplam 12 sorudan oluşan okuduğunu anlama metni yoluyla; matematik problem çözme becerilerine ilişkin veriler de toplam 6 açık uçlu sorudan oluşan problem çözme testi aracılığı ile toplanmıştır. Araştırmada, öğrencilerin problem çözme aşamalarında karşılaştıkları güçlüklerin belirlenmesi, okuduğunu anlama becerileri düzeylerine göre problem çözme süreçlerindeki davranışların derinlemesine incelenmesi amaçlandığından araştırma konusunun doğal ortamı içerisinde incelenmesini sağlayan nitel araştırma yöntemlerinden durum (örnek olay) çalışması kullanılmıştır. Bu kapsamda, araştırmaya katılan öğrenciler ile görüşmeler gerçekleştirilmiştir. Bu öğrenciler, 2018-2019 eğitim-öğretim yılında Kocaeli ilinde öğrenim gören toplam 90 üçüncü sinıf öğrencisi arasindan okuduğunu anlama düzeyine bağlı olarak yüksek-orta-düşük grubu temsil etmek üzere seçilen 6 üçüncü sını öğrencisidir. Elde edilen verilerin analizi betimsel istatistikler üzerinden incelenmiştir. Araştırma sonuçlarına göre, okuduğunu anlama seviyesi düşük olan öğrencilerin problem çözmenin tüm basamaklarında sorun yaşadığı, okudŭ̆u anlama düzeyi yüksek olan öğrencilerin ise problem çözme aşamalarında başarll olduğu ancak okuduğunu anlama düzeyine göre genel olarak çz̈̈zü̈n kontrol edilmesi ve problem kurma aşamalarında sorun yaşadıkları görülmüş̧ür. Elde edilen sonuçlar literatür ışı̆̆ında tartışılmış ve okuduğunu anlama düzeyine bağlı olarak problem çözümünde yaşanılan güçlükler için önerilerde bulunulmuştur.
\end{abstract}

Anahtar Kelimeler: Problem çözme, Matematik problemi, Okuma becerisi, Problemi anlama 


\title{
The Problem-Solving Achievements And The Difficulties In Solving Process Of Third Grade Students According To Reading Skills
}

\begin{abstract}
In this study, it is aimed to determine the problem-solving success of primary school third grade students according to their reading skills and their difficulties in problem solving process. The data were obtained through the reading comprehension text consisting of a total of 12 questions for the reading skills of the participants and six open-ended questions for mathematics problem solving skills. In the study, a case study (a qualitative one) was used because it was aimed to determine the difficulties faced by the students in problem solving stages and to investigate the behaviors in problem solving process according to their level of reading comprehension skills. With this aim, the interviews were conducted with the participant students consists of six third grade students, who represent high-middle-low group depending on the level of reading comprehension, selected from a total of ninety-third grade students in the province of Kocaeli in 2018-2019 academic year. The obtained data were analyzed using descriptive statistics. According to the results of the study, it was understood that the students with low level of reading comprehension had problems in all stages of problem solving while the students with high level of reading comprehension were successful in all problem-solving stages. Besides, these students had problems in controlling the solution and problem formation stages in general according to the level of reading comprehension. Additionally, the results were discussed in the light of the literature and suggestions were made for the difficulties in problem solving depending on the level of reading comprehension.
\end{abstract}

Keywords: Problem solving, Mathematical problem, Reading skills, Understanding of the problem 


\section{Giriş}

Bireyler, günlük hayatta karşılaştıkları sorunlarla başa çıkabilmek için çeşitli çözümler üretmeye çalışırlar. Bireylerin karşılaştıkları ve gelecekte yaşayacakları sorunlara etkili şekilde çözüm bulabilmeleri için de problem çözme becerilerine sahip olmaları gerekmektedir (Kaplan, Duran ve Baş, 2016). Bu durum öğrenci boyutunda değerlendirildiğinde, bilginin çok hızlı bir şekilde değişkenlik göstererek arttığı dijital çağda neyi, niçin ve nasıl öğrenmesi gerektiğini bilen, öğrendiği bilgileri aktif olarak kullanabilen ve çağa ayak uyduracak yeni bilgiler üretebilen bireylerin yetiştirilmesinde etkili olacaktır. Ayrıca, aile ve okulda alınan eğitim ile bireyin problem çözme becerilerinin gelişmesi ve bu konudaki potansiyellerinin ortaya çıkarılması da önemlidir (Gündüz ve Odabaşı, 2004; Güven ve Kürüm, 2008; Serin, Serin ve Saygilı, 2010). Bu nedenle, eğitim alanındaki hedeflerden biri de gelecekte karşılaşabileceği problemlere çözüm yolu üretebilen ve gerekli becerileri uygulayabilen donanımlı bireylerin yetiştirilmesini sağlamaktır (Özsoy, 2007). Bunun için de problemlere karşı hızlı bir şekilde çözüm arama ve üretme sürecinde, bireylerin yaratıcı düşünmeleri aktif hale getirilmeye çalışılmaktadır (Çenberci, 2018).

Türk Dil Kurumu (2019) sözlüğünde problem "Teoremler veya kurallar yardımıyla çözülmesi istenen soru, mesele" olarak ifade edilmektedir. Problem çözme ise; "önceden belirlenen ya da tasarlanan bir hedefe varmak için karşılaşılan güçlükleri ortadan kaldırmaya yönelik bireyin bilişsel, duyuşsal ve devinimsel becerilerini aktif olarak kullandığı durum ya da süreç" olarak açılanabilir (Kaplan vd., 2016; Tüysüz, 2013). Bireyin birçok beceriyi etkin bir şekilde kullandığı karmaşık bir süreç olan problem çözmenin öğeleri; "problemi anlama, verilenler arasında çözüm için gerekli bilgiyi seçme, elde edilen bilgileri matematiksel sembollere dönüştürme ve işlemler yaparak çözüme ulaşma" olarak ifade edilebilir (Ulu, Tertemiz ve Peker, 2016). Matematik alanı açısından değerlendirildiğinde ise, problem çözme "temel zihinsel beceri, matematik bilgisi ve işlemlerinin kullanılması ile süreç içerisinde sorunun ortadan kaldırılması"dır (Özsoy, 2006). Problem çözme ile matematiğin temel kavramlarının öğrenilmesi arasında da güçlü bir bağ bulunmaktadır (Birbiri, 2014; Kalaycı ve Hürriyetoğlu, 2018). Yapılan farklı araştırmalarda (Çelik ve Güler, 2013; Gökkurt, Örnek, Hayat ve Soylu, 2015; Işık ve Kar, 2011) da problem çözme ile matematik dersi 
arasındaki ilişki açıklanmaktadır. Ülkemizde özellikle de son yıllarda uygulamaya koyulan matematik ders programlarında da problem çözme becerisinin öneminin vurgulandığ1 görülmektedir (Birbiri, 2014; Çiftçi, Sezgin-Memnun ve Aydın, 2018). Milli Eğitim Bakanlığı tarafından hazırlanan 2018 yılı İlkokul Matematik Programı (MEB)'nın amaçları arasında, okullarda problem çözme ve problem kurma etkinliklerinin matematik öğretiminin önemli bir parçası olması gerektiği ve öğrencinin kendi düşünce ve akıl yürütmelerini ifade edebilecek ve matematiksel akıl yürütmelerindeki eksikliklerini fark edebilecek yeterlilikte olması yer almaktadır.

Özellikle de okuma becerilerinin geliştiği ve okuma alışkanlığının kazanıldığı ilkokul düzeyinde okuduğunu anlama neredeyse tüm derslerin işlenişinde başarıyı etkileyen önemli bir beceri olarak kabul edilmektedir (Baştuğ ve Keskin, 2012; Paris, 2017; Semizoğlu, 2013). Bu alanda yapılan araştırmalar (Çavuşoğlu, 2010; Hamurcu, 2016; İlhan, 2014; Özbilgin, 2018; Özçelik, 2011; Uçar, 2010; Uzun, 2010; Yıldız, 2013) okuduğunu anlama gücü ile diğer dersler arasında bir ilişki bulunduğuna, okuduğunu anlamada yetersiz olan öğrencilerin farklı ders konularına ilgi duyma düzeyi ve akademik başarı seviyelerinin de olumsuz etkilenebileceğine işaret etmektedir. Matematik dersi içerisinde akıcı ve anlam kurmaya yönelik, problemin güçlük derecesine uygun ve öğrenciyi aktif kılacak bir okuma anlayışı, öğrencinin problem çözme başarısını da olumlu şekilde etkileyebilir (Albayrak ve Erkal, 2003). Ayrıca, öğrencilerin matematik problemi çözme sürecinde uyguladıkları "verilen ve istenenleri ayırma", "probleme uygun şema oluşturma ya da şekil çizme" aşamalarında başarılı olmalarının ön şartı da öğrencilerin problemi doğru ve eksiksiz bir şekilde okumaları ve anlamalarıdır (Sert, 2010; Şengül ve Yalçın, 2004).

Bu konuda yapılan çalışmalara bakıldığında, Türkiye'de öğrencilerin okuduğunu anlama becerileri ve problem çözme başarılarını inceleyen farklı araştırmalara (Aydın-Akay, 2004; Boz, 2018; Çiftçi vd., 2018; Çolak, 2017; Göktaş, 2010; Ilgın, 2010; Karadedeli, 2018; Özcan, 2016; Polat, 2012; Tezgören, 2015; Tuohimaa, Aunola ve Nurmi, 2008; Türnüklü ve Yeşildere, 2014; Uçar, 2010; Uzun, 2010; Ulu vd., 2016) ulaşılmıştır. Bu araştırmalardan Çiftçi vd. (2018) tarafından yapılan çalışmada, ortaokul öğrencilerinin okuma becerileri ile matematik problemlerini çözme başarıları arasındaki ilişkiler incelenmiştir. Araştırmanın sonucunda, öğrencilerin ağırlıklı olarak matematiksel bilgi içeren problemlerde başarılı olduğu ancak mu- 
hakeme, analiz etme soyut düşünme becerisi ve matematik bilgileri ile harmanlamayı gerektiren problemlerde başarılı olamadıkları ifade edilmiştir. Öğrencilerin okuma becerileri ile problem çözme başarıları arasında orta düzeyde anlamlı ilişki bulunduğu da açıklanmıştır. Benzer şekilde, Göktaş (2010) tarafından yapılan araştırmanın sonucunda da ilköğretim ikinci kademe öğrencilerinin okuduğunu anlama becerisi ve matematik dersi başarısı arasında yüksek düzeyde ilişki olduğu sonucuna ulaşılmıştır. Semizoğlu (2013) yaptığı çalışmada ise, beşinci sınıf öğrencilerinin okuduğunu anlama ve görsel okuma düzeyi ile problem kurma becerisi arasındaki ilişki incelenmiştir. Bu araştırmanın sonucunda ise, okuduğunu anlama ve problem kurma becerilerinden alınan puanların cinsiyete göre k1z öğrenci lehine, anne-baba eğitim durumuna göre lise ve üniversite mezunu ailelerin çocukları lehine, Türkçe ve matematik dersi karne notu ile sosyo-ekonomik düzeye göre ise pozitif yönde anlamlı bir şekilde farklılık gösterdiği belirtilmiştir. Ayrıca, okuduğunu anlama ve görsel okuma beceri düzeylerine bağlı olarak öğrencilerin problem kurma beceri testi puanlarında anlamlı bir farklılık bulunduğu da araştırma sonucunda ifade edilmiştir. Yapılan farklı çalışmalarda (Boz, 2018; Çavuşoğlu, 2010; Tuohimaa vd., 2008) da yine okuma ve okuduğunu anlama becerilerinin öğrencilerin matematik başarısını olumlu yönde etkilediği raporlanmıştır. Jordan, Hanich ve Kaplan (2003) ise yaptıkları çalışma sonucunda okumada güçlük çeken öğrencilerin matematik eğitiminde problem çözümünde başarılarının düşük olduğunu açıklamışlardır. Karadedeli (2018) de yaptığı çalışmada, dördüncü sınıf öğrencilerinin eleştirel okuma ve problem çözme becerilerini incelemiştir. Çalışmanın sonucunda, eleştirel okuma beceri düzeyinde sorgulama, çıkarımda bulunma, benzerlikleri ve farklılıkları bulma, analiz ve değerlendirme alt boyutları ile problem çözme beceri düzeyleri arasında ise pozitif yönlü orta düzeyde bir ilişki bulunduğunu açıklamıştır. Ayrıca, öğrencilerin eleştirel okuma beceri puanları yükseldikçe problem çözme becerisinin de artış gösterdiği de ifade etmiştir. Türnüklü ve Yeşildere (2014) tarafından yapılan çalışmada da yine eleştirel düşünmenin etkili olduğu durumlar ile matematik başarısı ve problem çözme becerisi karşılaştırılmış ve bunlar arasında pozitif yönde ilişkiler bulunduğu da raporlanmıştır.

Bireylerin iyi bir okuma becerilerine sahip olması metni anlama, yorumlama ve problem çözme aşamalarını etkilemektedir (Çiftçi vd., 2018). 
Bu nedenle, okuduğunu anlama için problem çözme davranışları ile ilgili eğitim sisteminde gerekli çalışmaların yapılması ve öğrencilere bu becerilerin kazandırılması gerekmektedir (Bayrakçı, 2004). Alan yazın incelendiğinde, öğrencilerin okuma becerilerinin problem çözme başarılarına etkisini ileri yaş gruplarında inceleyen farklı çalışmalar (Çavuşoğlu, 2010; Çiftçi ve Temizyürek 2008; Göktaş, 2010; Semizoğlu, 2013; Uçar, 2010; Uzun, 2010) yapılmasına rağmen, ilkokul düzeyinde matematik dersinde yapılan sınırlı sayıda (Aydın-Akay, 2004; Boz, 2018) araştırmanın olduğu görülmektedir. Bu nedenle, yapılan bu çalışmada ilkokul üçüncü sınıf öğrencilerinin okuma becerileri ile problem çözme başarıları, okuduğunu anlama beceri düzeylerine göre problem çözme sürecinde yaşadıkları güçlüklerin incelenmesiyle, daha önce gerçekleştirilen çalışmalardan farklı olarak ilkokul düzeyinde matematik dersine yönelik problem çözme alanında araştırma kapsamı detaylandırılmış ve böylece de literatüre katkı sağlanması amaçlanmıştır. Bu çalışmada ilkokul üçüncü sınıf öğrencilerinin okuma becerileri ile problem çözme başarılarının incelenmesi amaçlanmıştır. Ayrıca, okuma becerilerine göre üçüncü sınıf öğrencilerinin problem çözme başarıları ve problem çözme sürecinde yaşadıkları güçlükler de araştırılmıştır. Bu amaçla aşağıdaki sorulara cevap aranmıştır:

1. İlkokul üçüncü sinıf öğrencilerinin okuma becerileri düzeyindeki farklılıklar öğrencilerin problem çözme başarısını nasıl etkilemektedir?

2. İlkokul üçüncü sınıf öğrencilerinin okuma beceri düzeylerindeki farklılıklara göre problem çözme sürecinde karşılaştıkları güçlükler nelerdir?

\section{Yöntem}

\section{Araştırmanın Modeli}

Farklı düzeyde okuduğunu anlama becerilerine sahip öğrencilerin matematik dersindeki problem çözme başarıları ve bu süreçte yaşadıkları güçlükleri inceleyen bu araştırmada nitel ya da nicel bir yaklaşımla gerçekleştirilebilen durum çalışması modeli tercih edilmiştir (Yıldırım ve Şimşek, 2008). Çalışmada belirli bir grup üzerinde yoğunlaşılması ve derinlemesine inceleme yapılması nedeniyle, çalışma durum çalışması özelliği taşı- 
maktadır. Durum çalışmaları belirli bir olgu, olay, birey veya grup üzerinde derinlemesine inceleme yaparak genel tarama modelleri ile yapilan araştırmalara oranla daha detaylı ve gerçeğe yakın bilgiler elde edilmesine imkân sağlamaktadır (Yin, 1984). Genel taramaların yapılacak araştırma için yetersiz görüldüğü durumlarda durum çalışmalarına başvurulmaktadır (Karasar, 2005). Durum çalışmasında, evrende belirli bir kitlenin ya da grubun kendisi ve çevresi arasındaki ilişkiler ne, niçin ve nasıl soruları kullanılarak derinlemesine incelenmesi ve belirlenmesi sağlanmaktadır (Çepni, 2012; Karasar, 2005).

\section{Çalışma Grubu}

Bu araştırma 2018-2019 eğitim öğretim yılı ikinci döneminde Türkiye'de Kocaeli ilinde bulunan bir devlet okulunda ilkokul üçüncü sınıfta öğrenim görmekte olan toplam 90 öğrenci içerisinden farklı okuma beceri düzeyine sahip ikisi kız ve dördü erkek olmak üzere toplam 6 öğrenci ile gerçekleştirilmiştir. Bu katılımcı öğrenciler, amaçlı örnekleme yönteminden maksimum çeşitlilik örneklemesi tekniğine göre belirlenmiştir. Bu örnekleme yönteminde, evrende incelenecek problemle ilgili olarak kendi içinde benzeşik ve farklı durumlar belirlenmekte ve çalışmada bu durumlar esas alınmaktadır. Çeşitlilik gösteren durumlar arasındaki benzerlik ve farklılıkların genelleme yapılmaksızın ortaya çıkarılmaktadır (Büyüköztürk vd., 2012; Yıldırım ve Şimşek, 2008).

Bu araştırmada da, araştırma kapsamına alınan okulda öğrenim görmekte olan üçüncü sınıf öğrencilerinin okuma beceri düzeylerine ilişkin bilgileri okuduğunu anlama metni uygulamaları doğrultusunda elde edilmiştir. Veri analizi kısmında detaylı biçimde bu metinlerin analizi açıklanmış ve ardından da okuduğunu anlama becerileri yüksek, orta ve düşük düzeyde olan ikişer öğrenci olmak üzere toplam 6 öğrenci belirlenmiştir. Bu öğrencilerin problem çözme süreçlerinde yaşadıkları sorunlar ve başarılarının incelenmesi araştırmada ulaşılmak istenen amaçlardan biridir. Bu nedenle, öğretmen görüşleri alınmış ve okuma beceri düzeyleri farklı olan öğrenci gruplarını temsil eden iki öğrencinin seçiminde, klinik mülakat esnasında kendini rahat bir şekilde ifade edebilecek öğrenciler olmasına da dikkat edilmiştir. Görüşmelerde öğrencilerin isimleri de gizli tutulmuş ve okuma düzeyi dü- 
şük öğrenciler K1, K2; orta düzeydeki öğrenciler O1, O2; okuma düzeyi yüksek olan öğrenciler Y1, Y2 şeklinde kodlanmıştır.

\section{Veri Toplama Araçları}

$\mathrm{Bu}$ araştırmada, öğrencilerin okuma becerilerine ilişkin bilgiler okuduğunu anlama metni kullanılarak, problem çözme becerileri ise problem çözme testi kullanılarak elde edilmiştir. Araştırmada veri toplamak amacıyla kullanılan ölçme araçlarına ilişkin ayrıntılı bilgi aşağıda sunulmuştur.

Matematiksel problem çözme testi: Öğrencilerin matematiksel problem çözme becerilerini ölçmek için problemler oluşturulurken araştırmacılar tarafından çalışma öncesinde, farklı kaynaklardan (dergi, kitap, tez, makale vb.) yararlanılarak ve Polya (1957)'nın problem çözme aşamalarını kullanmayı gerektirecek şekilde 12 adet açı uçlu rutin matematik problemi belirlenmiştir. Belirlenen problemlerin, Milli Eğitim Bakanlı̆̆ müfredatına dayalı devlet okullarında kullanılan üçüncü sınıf ders kitapları ile kaynak kitaplarındaki problem örneklerine uygunluğu incelenmiş, öğrencilerin seviyelerine uygun, kullanışlı, açık, anlaşılır ve problem çözme alt aşamalarına uygun 6 adet problem seçilmiştir. Alanında uzman iki tane sınıf öğretmeni ve bir öğretim üyesinin görüşü doğrultusunda gerekli inceleme ve düzenlemeler yapıldıktan sonra teste son şekli verilmiştir.

Bu sorulardan birinci, dördüncü, beşinci sorunun kazanımı "çarpma ve toplama ile ilgili problemler çözme", üçüncü ve altıncı sorunun kazanımı "bölme ile ilgili problemler çözme" ikinci sorunun kazanımı ise "toplama ve çıkarma ile ilgili problemler çözme"dir. Birinci ve ikinci soru üç adımlı, üçüncü soru bir adımlı, dördüncü soru dört adımlı, beşinci soru iki adımlı ve altıncı soru bir adımlı sorulardır. Öğrencilerin problem anlama, strateji belirleme, stratejiyi uygulama ve çözümü değerlendirme aşamalarındaki davranışların belirlemek amacıyla her bir problemin altında Polya'nın problem çözme basamaklarından her basamağa ilişkin bilgi elde edilmesini mümkün kılan açı uçlu sorulardan (problem kendi cümlelerinizle anladığınız şekilde ifade ediniz, problemde verilen ve isteneni yazınız, problemin çözümü için hangi stratejiler kullanılmalıdır?, problem farklı yolla çözebilir misiniz?, problemin çözümünü yapınız, örneğe benzer bir problem kurunuz.) bazıları seçilerek kullanılmıştır. Bu sorular da öğrenci- 
lerle yapılan mülakatlar esnasında sorulmuş ve öğrencilerin anlatarak çözmeleri istenmiştir. Aşağıdaki bu problemlere yer verilmiştir:

- P1. Dedemin 5 kuzusu ve 3 tavşanı 4 tane de güvercini vardır. Buna göre, çiftlikteki kuzu ve tavşanların ayak sayıları toplamı kaçtır?

- P2. İlknur 25TL ile firma gitti. Tanesi 1TL'den 5 ekmek, tanesi 50 kuruştan 8 tane kurabiye aldı. İlknur'un kaç TL'sinin kaldığını bulunuz.

- P3. Ece biriktirdiği 36 liranın 1/3'ü ile annesine anneler günü hediyesi almıştır. Ece'nin annesine aldığı hediye kaç liradır?

- P4. Annem $2 \mathrm{~kg}$ elma, $2 \mathrm{~kg}$ çilek ve $1 \mathrm{~kg}$ muz aldı. Annem aldığ 1 ürünler için manava kaç lira ödemiştir? (1kg elma:4lira, $1 \mathrm{~kg}$ çilek:9lira, $1 \mathrm{~kg}$ muz:15lira)

- P5. Ecrin'in dedesinin bahçesinde 32 tane elma ağacı vardır. Elma ağacının 2 katı kadar da kiraz ağacı vardır. Ecrin'in dedesinin bahçesindeki toplam ağaç sayısı kaçtır?

- P6. Duygu, bahçelerindeki armut ağaçlarından 56 tane armut topladı. Topladığı bu armutları poşetlere 4'erli bir şekilde paylaştırmak istedi. Duygu'nun kaç poşete ihtiyacı vardır?

Okuduğunu anlama sorularn: Araştırmanın uygulama sürecinde kullanılan metin üçüncü sınıflar için uygulanan konuyla ilgili yapılmış farklı kaynakların (tezler, makeleler, ders kitapları vb.) incelenmesi sonucunda bir araya getirilen ve sınıf düzeyine uygun kazanımları içeren (okuduklarında ne, nerede, ne zaman, nasil, niçin ve kim (5N 1K) sorularnna cevap arar, görsel okuma yapar vb.) 141 kelimelik okuma metninden yararlanılmıştır. Kazanımların seçiminde aynı amaca yönelik kazanımlardan uygun olanı seçilmiş ve sorularda net, açık, anlaşılır ifadelere yer verilmiştir. Metnin uygunluğu için sınıf öğretmenleri ve bir öğretim görevlisinin görüşü alınmış ve gerekli düzeltmeler yapılarak öğrencilere uygulaması gerçekleştirilmiştir. Devlet okulunda üç sinffta toplam 90 öğrenciye uygulaması gerçekleştirilen veri toplama aracının Cronbach alfa güvenilirlik katsayısı.823 olarak hesaplanmıştır. $\mathrm{Bu}$ durum ölçme aracının güvenilir olduğunu göstermektedir. Seçilen okuma metninde parçaya uygun şekilde $5 \mathrm{~N} 1 \mathrm{~K}$ (ne, ne aman, nerede, ne zaman, kim) ve okuduğunu anlama kapsamında 12 adet soru öğrencilere sorulmak üzere hazırlanmıştır. 


\section{Verilerin Toplanması ve Analizi}

Araştırmada kullanılacak verilerin elde edilebilmesi amacıyla araştırmacı tarafından okuma metni ve problem çözme testi 2018-2019 eğitim-öğretim yılının ikinci yarıyılında (Mayıs'ın ikinci haftası) uygulanmıştır.

İlk olarak araştırma kapsamına alınan okulun üçüncü sınıfında öğrenim görmekte olan öğrencilere Okuduğunu Anlama Metni uygulanmıştır. Ardından, görüşme yapılacak öğrencilerin seçilmesi için araştırmacı tarafından öğrencilerin cevapladıkları kağıtlar okunarak doğru cevaplanmış sorular için 10 puan, kısmen doğru cevaplanmış ve bilgi düzeyindeki sorular için 5 puan, hatalı cevaplanmış veya boş bırakılarak cevaplanmayan sorular için 0 puan şeklinde puanlama yapılmıştır. Ardından da, öğrencilerin toplam puanları hesaplanmış ve okuma puanı 0-24 arasında olanlar değerlendirmeye alınmamıştır. Metinde yer alan sorulardan aldıkları puanlar 25-54 arası olanlar düşük, 55-84 arası olanlar orta, 85-100 arası olanlar da yüksek puan alan öğrenci olarak kabul edilmiştir. Bu doğrultuda, okuduğunu anlama becerileri yüksek-orta-düşük olarak gruplandırılan öğrencilerden her grubu temsil edecek iki öğrenci belirlenmiş ve toplam 6 öğrenci araştırmaya katılmıştır.

Araştırmada, katılımc 6 öğrenciye problem çözme testinde yer alan problemler yöneltilmiştir. Uygulama aşamasında, katılımcı öğrencilere anlaşılmayan sorular için gerekli açıklamalar yapılmıştır. Öğrenciler tarafından matematik problem çözümleri sırasında yapmış oldukları işlemleri ve yaşadıkları güçlükleri derinlemesine incelemek amacıyla veriler gözlem ve klinik mülakat teknikleri kullanılarak toplanmıştır. Klinik görüşme, öğrencilerin matematik problemlerini çözme davranışları, matematiksel kavramları anlama ve ifade etmelerinin yanı sıra bilişsel ve biliş ötesi farklılıklarını gözlemleme ve ortaya koyma firsatı tanır (Goldin, 1998). Görüşme sürecine başlamadan önce öğrencinin rahat edeceği ve birebir çalışılabilecek bir görüşme ortamı oluşturulmuştur. Uygulamalar bireysel olarak veya okul içerisinde bulunan sınıf ortamında ve çok amaçlı toplantı salonunda gerçekleştirilmiştir. Uygulama esnasında, öğrencilerin problemleri sesli olarak okuyup çözmeleri istenmiş ve aynı zamanda problem çözmeye yönelik performansları kamera ve ses kaydı ile araştırmacı tarafından gerekli gözlemler yapılarak kayıt altına alınmıştır. Bu aşamada, öğrencilerden matematik problemlerini önce içinden bir kez sessiz oku- 
ması daha sonra da sesli olarak okuması istenmiş, okuduğu problemle ilgili ne anladığı sorulmuş, kendi cümleleri ile detaylı olarak açıklaması istenmiş ve problem çözme aşamalarına göre açık uçlu soruların alt soruları öğrencilere sorulmuştur. Öğrencilerin problem çözme sürecinde araştırmacı tarafından problemlerin anlaşılmadığı ve çözümlerde zorlanıldığı durumlarda, öğrencilere sonucu etkilemeyecek ve sadece anlaşılmayan durumlara cevap olacak biçimde yönlendirici sorular (problemden ne anladıkların bana sözlü olarak söyleyebilir misin?, Problemde verilen ve istenenlerin neler olduğunu söyleyebilir misin? vb.) yöneltilmiştir. Bu aşamada da, öğrencilerin her bir soruyu çözme aşamasında nasıl yaptıklarını ifade etmeleri istenmiş, öğrencilerin yaptıkları hatalara ve zorlandıkları aşamalara göre farklı sorular yöneltilerek belirli kuralları ezberleyerek mi yoksa anlamlı şekilde mi çözmeye çalıştıklarını öğrenmek için uyguladıkları stratejiyi anlatmaları istenmiştir.

Her öğrenci için görüşmeler ortalama 45-60 dk. aralığında gerçekleşmiştir. Görüşmelerin sonunda ses ve video kayıtları yazı haline dönüştürülmüş, öğrencilerin okuduğunu anlama seviyesine uygun olarak problem çözme basamaklarında yaşadıkları sorunlar tespit edilmiştir. Ardından da, bu analizler sonucunda ulaşılan bilgiler önce tablolar halinde sunulmuş ve her bölümde bir öğrencinin çözüm sürecindeki cevaplarına ve araştırmacı ile diyaloglarına yer verilmiştir.

Araştırmaya katılan öğrencilerin bu araştırmada yer alan problem çözme testine verdikleri cevaplar, nitel analiz yöntemlerinden betimsel analiz kullanılarak çözümlenmiştir. Betimsel analiz yöntemine göre elde edilen veriler, önceden belirlenen temalara göre özetlenir, yorumlanır, sonuçlar ortaya konulur ve görüşme yapılan katılımcıların görüşlerini yansıtmak amaciyla doğrudan alıntılara başvurulur. Dört aşamadan oluşan betimsel analizde ilk aşama analiz çerçevesinin (temaların) belirlenmesi, ikinci aşama tematik çerçeveye göre verilerin işlenmesi, üçüncü aşama bulguların tanımlanması ve son aşama bulguların yorumlanmasıdır. Araştırma probleminin ortaya çıkardığı temalara göre veriler düzenlenip ilişkilendirilebilir ya da görüşme ve gözlem boyunca yöneltilen sorular ele al1narak da veriler sunulabilir (Yıldırım ve Şimşek, 2008). Katılımcı öğrencilerin problem çözme esnasında yaşadıkları sorunları ve problem çözme süreçleri, her problemin içerisinde bulunan alt sorulara verdikleri yanitlar incelenirken, Polya'nın problem çözme basamaklarına göre betimsel ana- 
liz yapılmıştır. Betimsel analiz için analiz çerçevesinin (temaların) belirlenmesi aşamasında; temalar "problemi anlama", "plan hazırlama/ stratejinin belirlenmesi", "stratejinin uygulanması", ve "değerlendirme/kontrol" olarak belirlenmiştir. Verilerin işlenmesi aşamasında, problem çözme esnasında yüksek-orta-düşük düzeyde okuma becerilerine sahip öğrencilerin yaşadıkları sorunlar ve problem çözme sürecindeki davranışları incelenmiş ve elde edilen veriler bu temalar altında düzenlenmiştir. Son olarak tanımlanan veriler bulgular bölümünde temalar altında yorumlanmış ve öğrencilerle ilgili problem çözme esnasındaki davranışları ve yaptıkları işlemler doğrudan alıntılarla desteklenerek teyit edilebilirlik sağlanmıştır. Teyit edilebilirlik nitel araştırmalarda araştırmacının topladığ 1 verilerde beklenen sonuçları çalışma içerisinde sıkça yer vermesi ile sağlanmaktadır. Çalışma bulgularında veriler aktarılırken akla yatkınlık, inandırıcılık, önem ve okunurluk özelliklerini barındırılmasına da önem verilmiştir.

Yapılan görüşmeler sonucunda, öğrencilerin problemleri çözdüğü çalışma kağıdından alıntılara ve görsellere bulgular bölümünde detaylı şekilde yer verilmiştir. Bu araştırma kapsamında yer alan bu bilgiler ve başvurulan uzman görüşleri ile araştırmanın geçerlik ve güvenilirliği de sağlanmaya çalışılmıştır.

\section{Bulgular}

Bu kısımda, araştırmaya katılan 6 üçüncü sınıf öğrencisinin araştırma kapsamında gerçekleştirilen görüşmelerde kendilerine yöneltilen problemlere verdikleri cevaplardan elde edilen problem çözme aşamasına yönelik cevaplar her bir problem için ayrı ayrı tablolar halinde sunulmuştur. Her bir problem için sunulan tablonun ardından belirlenen bir öğrencinin çözüm sürecindeki cevaplarına ve araştırmacı ile diyaloglarına yer verilmiştir. Bu kapsamda, katılımcı öğrencilerin birinci problem (P1) için çözüm aşamasına yönelik yaşadığı güçlüklere ilişkin cevaplardan elde edilen bulgulara aşağıda yer alan Tablo 1'de yer verilmiştir. Bu tabloda, problemin çözümüne ilişkin okuma becerilerine göre problem çözme aşamalarında sorun yaşayan öğrencilerin kodları ilgili bölümde gösterilmiştir. 
Tablo 1. P1'in Çözüm Aşamasına Yönelik Cevaplardan Ulaşılan Bulgular

\begin{tabular}{lllll}
\hline Problemi Anlama & Stratejinin Belirlenmesi & Uygulama & Değerlendirme \\
\hline Hiç Anlamayan & Eksik Anlayan & & & \\
\hline K2 & O2 & K2 & K1 & K2 \\
K1 & & O1 & & K1 \\
& & K1 & & \\
\hline
\end{tabular}

Burada yer alan Tablo 1'e göre, araştırmaya katılan öğrencilerden düşük ve orta düzeyde okuma becerisine sahip olan öğrenciler "problemi anlama" ve "stratejinin belirlenmesi" aşamasında sorun yaşamışlardır. Araştırmaya katılan öğrencilerin cevap kağıtları detaylı incelendiğinde, "problemi anlama" basamağında sorun yaşayan öğrencilerin problemi kendi cümleleri ile ifade etmede, verilen ve istenene karar vermede güçlük yaşadıkları tespit edilmiştir. Bu bağlamda P1 probleminin çözümünde, okuduğunu anlama becerisi düşük olan K1 öğrencisinin problem çözme basamaklarını neredeyse tamamında hatalı yargilara vararak problemi hatalı çözdügü, yine düşük becerili K2 öğrencisinin de kendisine yöneltilen uyarıcı sorular ışığında problemi doğru çözebildiği anlaşılmıştır. Bununla birlikte, okuduğunu anlama becerisi orta düzeyde olan $\mathrm{O} 2$ öğrencisinin ise "stratejinin belirlenmesi" basamağında sıkıntı yaşadığı ancak diğer basamakları doğru şekilde yaptığı görülmüştür. Okuduğunu anlama becerisi yüksek olan Y1, Y2 ve orta olan O1 kodlu öğrenciler ise problem çözümünü ve basamakların uygulanışını doğru şekilde yapmışlardır. Bununla birlikte, O1 kodlu öğrencinin problem çözme aşamalarından "stratejinin belirlenmesi" aşamasında araştırmacının uyarısının ardından stratejisini değiştirdiği ve doğru strateji kullanımının ardından da çözüme ulaştığ1 yapılan görüşme kayıtlarından anlaşılmıştır. Okuduğunu anlama becerisi yüksek olan Y1 ve Y2 öğrencilerinin "problemi anlama" aşamasında, problem içerisinde doğru sonucu buldukları görülmüştür. Aşağ1daki şekilde düşük anlama düzeyi olan K1 öğrencisinin "problemi anlama" aşamasına ilişkin cevabı yer almaktadır.

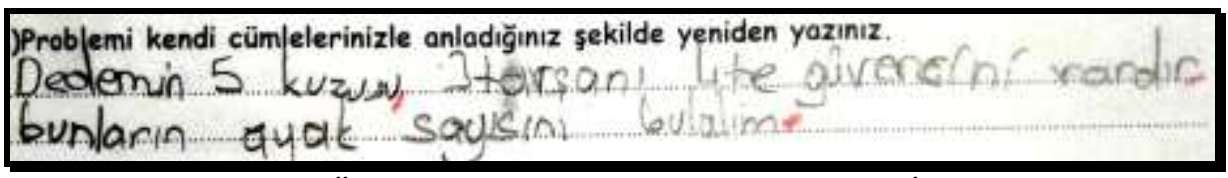

Şekil 1. K1 Kodlu Öğrencinin Problemi Anlama Aşamasına İlişkin Cevabı 
Aşağıda araştırmacı ve öğrenci arasındaki geçen konuşmalardan verilen alıntı da bu açılamayı destekler niteliktedir.

A1: Problemi yüksek sesle okuduktan sonra problemden ne anladıklarmı bana sözlü olarak söyleyebilir misin?

K1: Öğretmenim dedemin 5 kuzusu varmış. Üçte tavşanı varmış. Dört tane de güvercini varmış. Bunların ayak sayılarının toplamı kaçtı diyor.

1: Problemde verilen ve istenenler nelerdir?

1: Dedemin 3 kuzusu ,4 tavşanı ve güvercini vardır.

1: Evet, peki istenen nedir?

1: Bunların ayak sayısı toplamı kaçtır?

Yukarıda K1 öğrencisi ve araştırmacı arasında geçen diyalog ile Şekil 1 birlikte düşünüldügüunde, K1 öğrencisinin problemde verilen bilgiler arasında istenilen bilgiyi doğru anlamaması nedeni ile bütün verileri kullanarak çözüme gitmeye çalıştığı için hatalı çözüm yaptığı düşünülmektedir. Aşağıda K1 öğrencisinin problem çözme sırasında; "stratejinin belirlenmesi" ve "stratejinin uygulanması" aşamasında çözüme nasıl gittiği ile ilgili araştırmacı ile aralarında geçen diyalog verilmiştir.

A1: Problemin çözümü için hangi işlem yapılmalıdır?

K1: Çarpma.

A1:Çarpma mı? Peki seçtiğin çözümde bütün bilgileri kullanmış oluyor musun?

K1: Evet. (Katılımcının problem çözümü şekil 2'de gösterilmiştir.)

A1: Neden 5 ile 4'ü çarpmayı seçtin?

K1: Öğretmenim kuzuların 4 ayă̆̆ vardır.

A1: Şimdi ne yapacaksin?

K1: 20 ile 5'içarpacağız Ay toplayacă̆ız.

A1: 20 ile 5'i neden toplamayı seçtin?

K1: Öğretmenim çünkü 5 ile 4'ü çarptık 20 çıtı.

A1: Şimdi hangi işlemi yapacaksın? Kimin ayak sayılarını bulacağız?

K1: Tavşanla güvercinin. (20 ile 5'ı toplar.) Öğretmenim 20 ile 5'i toplayınca 25 çıkıyor.

A1: 25 ile neyi bulmuş oldun?

K1: Tavşan ile güvercini.

A1:Tavşan ile güvercin sayılarını mı? Emin misin? Ilk başta kimin ayak sayısını bulmuştun?

K1: (20 ve 5 ile toplama işlemini siler.) Illk başta kuzunun.

A1: 4 tane o zaman tavşanın ayak sayısımı nasıl bulabiliriz? 
K1: 4 ile 20'yi toplayarak.

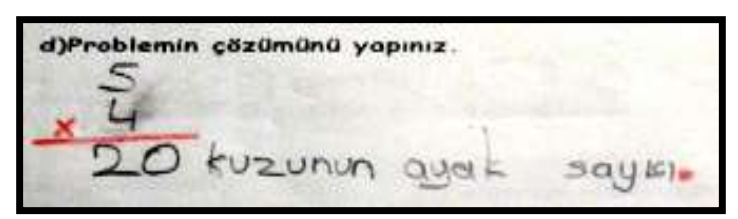

Şekil 2. K1 Kodlu Öğrencinin Uygulama Aşaması Için Cevabı

Yukarıda Şekil 2'de K1 öğrencisinin P1 problem çözme basamaklarından "uygulama" aşamasına ait çözümü ve araştırmacı olan ile diyaloğu bir arada incelendiğinde, K1 öğrencisinin ayak sayısını hesaplamada yapilacak olan işlemin çarpma işlemi olduğuna doğru karar verdiği ancak çözüme devam eden işlemlerde verileri anlamamasından dolayı güçlük çektiği ve hatalı işlemler yaptığı görülmektedir. Tablo 2'de ise, katılımcı öğrencilerin P2 için "stratejinin uygulanması" aşamasına yönelik yaşadığı güçlükler ve cevaplardan elde edilen bulgular verilmiştir.

Tablo 2. P2'nin Çözüm Aşamasına Yönelik Cevaplardan Ulaşılan Bulgular

\begin{tabular}{lllll}
\hline \multicolumn{2}{l}{ Problemin Anlaşılmas1 } & Str.nin Belirlenmesi & Uygulama & Değerlendirme \\
\hline Hiç Anlamayan & Eksik Anl. & & & \\
\hline & K2 & K1 & K2 & O2 \\
& K1 & K2 & K1 & K1 \\
& O2 & & & Y1 \\
& & & K2 \\
\hline
\end{tabular}

Tablo 2'den okuduğunu anlama becerisi düşük olan K1, K2 ve orta düzeyde okuma becerisine sahip olan $\mathrm{O} 2$ kodlu öğrencilerin verilenleri eksik ya da hatalı anlamalarından dolayı "problemi anlama" aşamasında sorun yaşadıkları, "stratejinin belirlenmesi" aşamasında ise K1 ve K2 kodlu öğrencinin uygun strateji belirleyemediği ve "uygulama" aşamasında doğru sonuca ulaşamadığı görülmektedir. Okuduğunu anlama becerisi yüksek olan Y2 ve orta olan O1 kodlu öğrenciler sorunun tüm aşamalarını doğru şekilde yapmıştır. "Değerlendirme/kontrol" aşamasinda O2, K1, Y1 ve K2 kodlu öğrencilerin problem kurması istendiğinde verilen problemin değerlerini değiştirerek yeni bir problem oluşturmaya çalıştığı ancak çözüme ulaşabilecek bir problem kuramadıkları ve mantık hatası yaptıkları tabloda görülmektedir. Bu aşamada, araştırmacı 
tarafından yöneltilen sorular ile $\mathrm{O} 2$ ve $\mathrm{Y} 1$ kodlu öğrencilerin hatayı fark ederek kurdukları problemi çözülebilecek şekilde düzeltmeye çalışmışlardır. Bu durum ile ilgili Şekil 3'de Y1 kodlu katılımcı öğrencinin problem kurmaya yönelik cevabı ve araştırmacı ile diyalogları verilmiştir.

Y1: Bu probleme benzer bir problem kurunuz.

A1: Çözdüğ̈̈n probleme benzer bir problem kurabilir misin?

Y1:(Öğrenci yazarken ayn zamanda sözlü olarak söyler). Tuğçe 33TL ile firma gitti. Tanesi 3 TL'den ekmek, tanesi 1TL'den 9 kurabiye aldi. Tuğģce'nin kaç TL'si kalır?

A1: Tuğçe'nin kaç lirası var kurduğun soruda?

Y1:33 lira

A1:Tuğçe kaç tane ekmek alıyor?

Y1:Yazmadim.

A1:Peki kaç tane ekmek aldığın yazmazsan kurduğun problem çözülebilir mi? Y1:Hayır. (Soruya ekleme yapar.) 6 ekmek.

A1: Kurduğun problemde Tuğçe tanesi kaç TL'dan kurabiye aldı?

Y1:1 TL'den 9 kurabiye.

A1:Peki problemde istenen nedir?

Y1:Tuğçe'nin kaç TL'si kalır?

A1: Kurduğun problemi başka bir arkadaşın çözebilir mi?

Y1:Çözebilir.

A1: Kurduğun problemde verilenlerde eksik bilgi olursa çözülebilir mi?

Y1: Hayır. Bunu çözemeyiz.

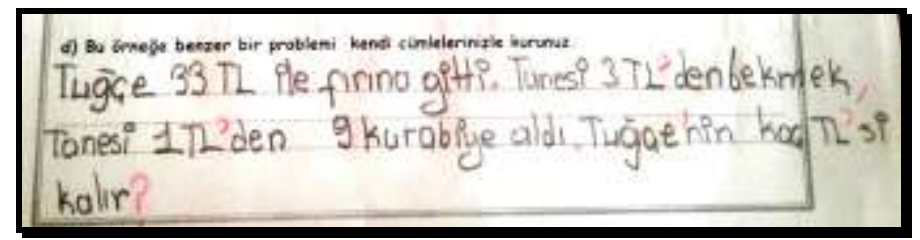

Şekil 3. Y1 Kodlu Öğrencinin Problem Kurmaya ilişkin Cevabı

Yukarıda verilen Şekil 3 ve Y1 öğrencisi ile araştırmacı arasında geçen diyaloglar birlikte değerlendirildiğinde; Y1 öğrencisinin başlangiçta verilen P2 problemindeki verileri sadece sayısal olarak ama eksik bir şekilde değiştirerek çözümü olmayan benzer problem kurmaya çalıştığ 1 görülmüştür. Araştırmacının yönlendirdiği sorular doğrultusunda da 
eksik bilgiyi fark ederek benzer doğru bir problem yazması ise yüksek anlama becerisine sahip olan Y1 öğrencisinin beklenenden düşük bir performans sergilediğini düşündürmektedir. Aşağıda okuduğunu anlama seviyesi orta düzey olan $\mathrm{O} 2$ öğrencisi ile araştırmacı arasında geçen diyaloglara yer verilmiştir.

O2: Bu probleme benzer bir problem kurunuz.

A1: Çözdüğ̈̈n probleme benzer bir problem kurabilir misin?

O2: (Problem cümlesi yazmaya başlar).

A1: İlknur'un kaç lirası var kurduğun sorunda?

O2:30 lira.

A1: Çözdü̆̆̈̈n soruda ekmek ve kurabiye alındı. Kurduğun soruda İlknur marketten ne ald??

O2: Çikolata ve lolipop.

A1: Kaç liralık çikolata ve lolipop aldı?

O2:4 tane.

A1:5TL'ye 4 tanesi 2 lira olan lolipoplardan 5 tane aldr.

O2: (Düşünür).

A1: Neyi fark ettin?

O2:Eksik.

A1:Nerede?

O2:Şey. 5TL 4 tanesi.

A1: Eksik olan nedir peki?

O2:Çikolata.

A1: Kurduğun problemde istenen nedir?

O2: Illknur'un kaç TL'sinin kaldığg.

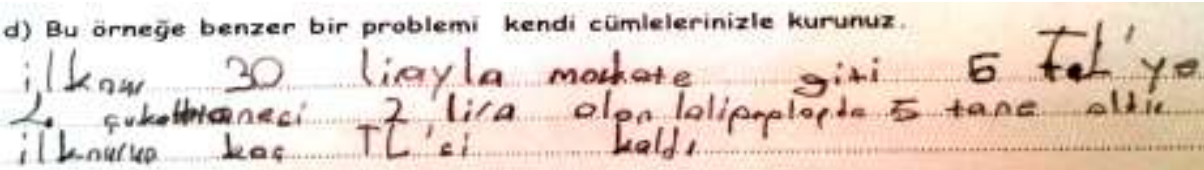

Şekil 4. O2 Kodlu Öğrencinin Problem Kurmaya Ilişkin Cevabı

Araştırma kapsamında yukarıda verilen $\mathrm{O} 2$ öğrencisinin problem kurma aşamasına ilişkin cevabının incelendiği Şekil 4 ve O2 öğrencisi ile araştırmacı arasında geçen diyaloglar birlikte değerlendirildiğinde, O2 öğrencisinin "değerlendirme" aşaması kapsamında eksik verilerle 
çözümü olmayan benzer problem kurduğu görülmüş olup; araştırmacı tarafından yöneltilen sorular doğrultusunda mevcut bilgilerle çözülebilen benzer doğru bir problem cümlesi yazdığı bulunmuştur. Tablo 3'de katılımcı öğrencilerin P3 için çözüm aşamasına yönelik yaşadığı güçlükler ve cevaplardan elde edilen bulgular verilmiştir.

Tablo 3. P3'ün Çözüm Aşamasına Yönelik Cevaplardan Ulaşılan Bulgular

\begin{tabular}{lllll}
\hline Problemi Anlama & & Str.nin Belirlenmesi & Uygulama & Değerlendirme \\
\hline Hiç Anlamayan & Eksik Anl. & & & \\
\hline & O1 & K1 & O2 & K1 \\
K1 & K2 & & \\
K2 & & & \\
Y2 & & & \\
\hline
\end{tabular}

Yukarıdaki tabloda O1, K1, K2, Y2 kodlu öğrencilerin "problemi anlama" aşamasında şekil çizme stratejisinde sorun yaşadıkları ve problemde onları doğru çözüme ulaştıracak şekil çizme stratejisi ile ilgili olarak bu soruda hatalı çizim yaptıkları veya boş bıraktıkları görülmüştür. Okuduğunu anlama becerisi yüksek olan Y1 kodlu öğrenci sorunun tüm basamaklarını doğru şekilde yapmıştır. Okuduğunu anlama becerisi düşük olan K1, K2 kodlu öğrencinin "strateji belirleme" ve K1'in "değerlendirme/kontrol" aşamasında sıkıntı yaşadığı ve soru üzerine düşünmeden hemen bir işlem söyledikleri görülmektedir. Bu bağlamda, araştırmaya katılan öğrencilerin araştırmacının yönlendirdiği sorular doğrultusunda doğru çözüme gitmeleri, problemin çözümünde mantıksal gerekçeyi açıklayamadıkları, çözüme giden işlemlerde ezbere işlem yaptıklarını düşündürmektedir. Araştırma kapsamında okuduğunu anlama becerisi orta düzeyde olan O2 öğrencisinin, yapılan klinik mülakatta P3 problemi için şekil çizerek ve zihinsel işlem yaparak doğru çözüme ulaşmasına rağmen cevap kâğıdı incelendiğinde problem çözme basamaklarından "uygulama" aşamasında hata yapmış olması, O2 öğrencisinin bölme işlemi kullanılmasını gerektiren bu problemde işlemsel bilgi açısından sıkıntı yaşadığı ya da bu durumun dikkat eksikliğinden kaynaklandığı düşüncesine götürmektedir. Öğrenciler soruları alışmış oldukları şekilde çözmeye çalışarak sayısal verileri kullanmışlardır. Şekil 5 'de ise soruyu şekille doğru çözen Y1 kodlu öğrencinin kağıdından bir örneğe ve araştırmacı ile aralarında geçen diyaloğa yer verilmiştir. 
Y1: (Sesli şekilde okur).Problem de verilen ve istenenlere uygun şekil çiziniz. A1: Problemde verilen ve istenilenler nelerdir?

Y1: Problemde verilen Ece biriktirdiği paranın bir bölü üçü ile annesine anneler günü hediyesi alacak. Ece'nin annesine aldığg hediye kaç liradır? Bunu bulmamizl istiyor.

A1: Buna uygun şekil çizebilir misin?

Y1: Şekil. Şimdi (çok kısa bir süre düşünür) payda kadar şekil çizelim. Bir, iki, üç (bir bütünü üç parçaya böler). Şimdi bir tanesini boyayacağız.

A1: O zaman bu şeklin tamamı neyi ifade ediyor?

Y1: Hımm (biraz düşünür). Ece'nin annesine aldığı 36 lira.

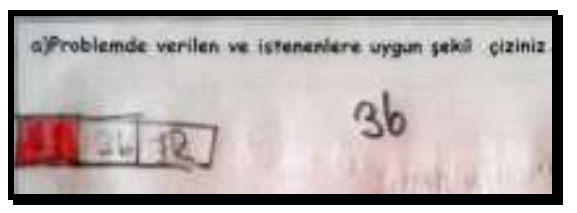

Şekil 5. Y1 Kodlu Öğrencinin Problemi Anlama Aşaması İçin Cevabı

Yukarıda verilen Şekil 5 ve Y2 öğrencisi ile araştırmacı arasında geçen diyaloglar birlikte değerlendirildiğinde; Y2 öğrencisinin problemde verilen ve istenen bilgilere doğru karar vererek; araştırmacının yönlendirdiği sorular doğrultusunda bu bilgiler arasındaki ilişkiyi doğru olarak belirlediği ve uygun şekil çizdiği görülmektedir. Şekil 6'da okuduğunu anlama seviyesi yüksek düzey olan Y2 kodlu öğrencinin ise şekil çizme esnasında verdiği cevap ve araştırmacı ile diyalogları yer almaktadır.

Y1: (Sesli şekilde okur). Problemde verilen ve istenenlere uygun şekil çiziniz. A1: Buna uygun şekil çizebilir misin?

Y2: Bir kumbara çizelim. İstenene uygun da kaç parası kaldığını eksildiğini yapalım. (2. kumbarayı gösterir) Kumbarasından paraların aldı.

A1: Evet. Başka bir şekil çizebilir miydik?

Y2: Mesela ne çizebiliriz? (Düşünür).

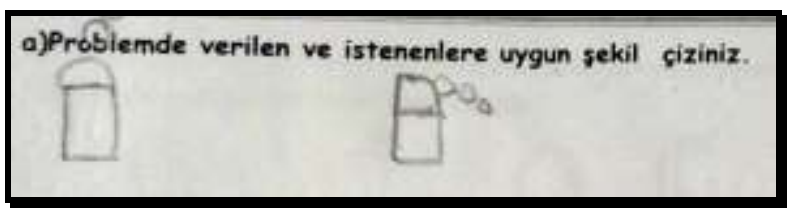

Şekil 6. Y2 Kodlu Öğrencinin Problemi Anlama Aşaması için Cevabı 
Araştırma kapsamında yukarıda verilen Y2 öğrencisinin "problemi anlama" aşamasına ilişkin cevabının incelendiği Şekil 6 ve araştırmacı ile arasında geçen diyaloglar birlikte değerlendirildiğinde, Y2 öğrencisinin "problemi anlama" aşamasında, yapılacak olan bir harcama sonrası parasında eksilme olacağına karar verdiği ancak çözüme uygun şekil çizemediği, uygun stratejiyi seçemediği için strateji bilgisinin yetersiz olduğu düşünülmektedir. Tablo 4'te katılıma öğrencilerin P4 için "uygulama" aşamasına yönelik yaşadığı güçlükler ve cevaplardan elde edilen bulgular verilmiştir.

Tablo 4. P4'ün Çözüm Aşamasına Yönelik Cevaplardan Ulaşılan Bulgular

\begin{tabular}{lllll}
\hline Problemi Anlama & & Str.nin Belirlenmesi & Uygulama & Değerlendirme \\
\hline Hiç Anlamayan & Eksik Anl. & & & \\
& & K2 & K2 & K2 \\
& & K1 & K1 \\
\hline
\end{tabular}

Tablo 4 incelendiğinde, okuduğunu anlama düzeyi yüksek ve orta olan Y1, Y2, O1 ve O2 tüm basamakları doğru şekilde yaparken, okuduğunu anlama düzeyi düşük olan K1 ve K2 kodlu öğrencilerin "problemi anlama" aşamasında doğru açıklama yapmalarına rağmen, "strateji belirleme", "uygulama" ve "değerlendirme/kontrol" aşamalarında sorun yaşadıkları ve problemle ilgili anlam bilgisini kullanamadıkları ve öğrencilerin stratejinin uygulanması aşamasında seçtiği işlemlerin nedenini tam olarak ifade edemedikleri görülmektedir. Bu durumda, araştırmaya katılan öğrencilerin problem ifadesi ile seçilen işlem arasında mantıksal ilişki kuramadıklar1 ve problem çözme becerilerinin geliştirilmeye ihtiyacı olduğu düşünülmektedir. "Değerlendirme/kontrol" aşamasında, araştırmacı tarafından yönlendirici sorular sorulmasına rağmen $\mathrm{K} 2$ öğrencisinin problem kurmakta zorlanarak çalışma kağıdını boş bıraktığı ve K1'in ise çözüme ulaşabilecek bir problem kuramadığ1 görülmektedir. Şekil 7'de K1 kodlu katılımcı öğrencinin " uygulama" aşamasına yönelik cevabı ve araştırmacı ile diyalogları verilmiştir.

K1:(Sesli şekilde okur). Problemin çözümünü yapını.

K1: (Problemin çözümünü yapar.) 
A1: Önce birinci işlemi ele alalım. Neden dokuz ile dördü çarpmayı seçtin? Çarpma ile neyin fiyatını bulmuş oluyorsun?

K1: Öğretmenim çarpma ile çilek ve elmanın.

A1: Peki 36 ile 15'i toplayarak neyin fiyatını bulmuş oldun?

K1: Toplama ile de muzun ve eriğin.

A1: Muzun ve eriğin fiyatını bulmuş oldun. Manava peki kaç lira ödenmiş? K1:51

A1: 51 lira ödemiş. Peki sorunun çözümü için neden çarpma ve toplama işlemlerini seçtin?

K1: Öğretmenim çünkü burada dokuz ile dört var (yaptı̆̆ işlemi gösterir) Dokuz ile dördü çarptım. Otuz altı çıktı. Otuz altı ile de on beşi topladım.

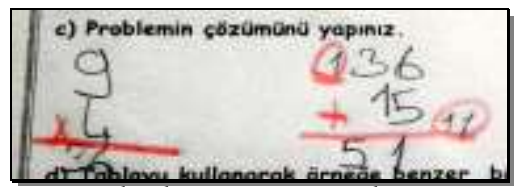

Şekil 7. Okuma Becerisi Düşük olan K1'in Uygulama Aşamasına ilişkin Cevabı

Araştırma kapsamında yukarıda verilen K1 öğrencisinin "stratejinin uygulanması" aşamasına ilişkin cevabının incelendiği Şekil 7 ve araştırmacı ile arasında geçen diyaloglar birlikte değerlendirildiğinde, K1'in kurduğu işlemlerin ne anlam ifade ettiğini bilmediği için çözüme yönelik hatalı işlemler yaptığı görülmektedir. Şekil 8 'de ise okuduğunu anlama becerisi orta düzey olan $\mathrm{O} 2$ kodlu katılımcı öğrencinin "stratejinin uygulanması" aşamasına yönelik doğru cevabı ve araştırmacı ile diyalogları yer almaktadir.

O2:(Sesli şekilde okur). Problemin çz̈̈münü yapını.

A1: Problemde verilen ve istenenler nelerdi?

O2: 41(zihninden işlemleri yapar). Elma (düşünür) 8 lira. (Kă̆̆ıına yazar).

A1: Burada 8 lira yazdın. Neyi bulmuş oldun?

O2: Toplamda elmaya ne kadar ödediğini.

A1: 18 lira ile neyi bulmuş oldun?

O2: Çilek 18 liraydı.

A1: Peki 41 lira ile neyi bulmuş oldun?

O2: 41 lirada bulduğumuz meyveler toplamı.

A1: Problemin çözümünde neden toplamayı seçtin? 
O2:Mesela şey demiş ki manava kaç lira ödemiştir diyor.

A1:Peki meyvelerin fiyatlarını hangi işlemi yaparak buldun?

O2:Şey ilk önce tabloya baktım. Çarpma işlemi ile buldum. Çileği de aynı şekilde buldum bunu da (elmayı gösterir) aynı şekilde buldum.

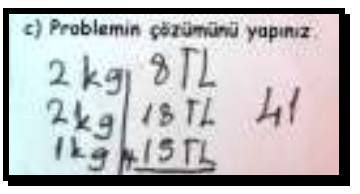

Şekil 8. Okuma Becerisi Orta Düzeyde olan O2'in Uygulama Aşaması için Cevabı

Araştırma kapsamında yukarıda verilen $\mathrm{O} 2$ öğrencisinin "uygulama" aşamasına ilişkin cevabının incelendiği Şekil 8 ve araştırmacı ile arasında geçen diyaloglar birlikte değerlendirildiğinde, $\mathrm{O} 2$ öğrencisinin problemi anladığı, problemin çözümü için uygun stratejiyi belirlediği ve zihinsel yapılan hesaplamalar ile doğru sonuca ulaştı̆̆ bulunmuştur. Problemde verilen ve istenileni belirleyerek bunlar arasındaki ilişkiyi saptayarak çözüm sürecinde anlam bilgisini kullanmış ve bulduğu değerlerin neyi ifade ettiğini, problemin çözülmesinde seçtiği işlemleri doğru şekilde açıklamıştır. Tablo 5'te katılımcı öğrencilerin P5 için "uygulama" aşamasına yönelik yaşadığı güçlükler ve cevaplardan elde edilen bulgular verilmiştir.

Tablo 5. P5'in Çözüm Aşamasına Yönelik Cevaplardan Ulaşılan Bulgular

\begin{tabular}{lllll}
\hline Problemi Anlama & & Str.nin Belirlenmesi & Uygulama & Değerlendirme \\
\hline Hiç Anlamayan & Eksik Anl. & & & \\
\hline & O1 & K2 & K2 & K2 \\
& K2 & K1 & & K1 \\
\hline
\end{tabular}

Tablo 5 incelendiğinde, okuduğunu anlama becerisi yüksek düzey olan Y1, Y2 ve orta olan O2 kodlu öğrencilerin tüm basamakları doğru şekilde yaptığı görülmektedir. Detaylı şekilde incelendiğinde, okuduğunu anlama düzeyi orta olan $\mathrm{O} 1$ ve O2 kodlu öğrencilerin "problemi anlama" aşamasında problemde istenileni çalışma kağıdına yazmadıkları görülmektedir. Bununla birlikte, yapılan görüşmelerde araştırmacı tarafından sorulan sorularda sözlü olarak problemde verilen ve istenileni doğru şekilde ifade etmeleri ve problem çözmenin diğer basamaklarında sorun yaşamamaları bu 
durumun dikkat eksikliğinden kaynaklandığını gösterebilir. Okuduğunu anlama düzeyi düşük olan K2 kodlu öğrencinin problem çözme basamaklarının dördünde de güçlük çektiği ve araştırmacının problem çözerken neler düşündüğünü incelemek için sorduğunu yönlendirici sorulara rağmen, problemde geçen ilişkisel ifadeleri açıklayamadığ dikkat etmediği için problemi çözemediği, okuduğunu anlama düzeyi düşük olan K1'in ise "stratejinin belirlenmesi" aşamasında zorlandığı ancak "uygulama" aşamasında araştırmacının sorularına verdiği cevaplardan problem çözümüne yönelik doğru işlemi uyguladığı görülmektedir. Araştırmaya katılan $\mathrm{Y} 1, \mathrm{Y} 2$ ve $\mathrm{O} 2$ öğrencilerinin problem çözme basamaklarını, problem durumunu doğru yanitlayarak, işlemsel hatalar olmadan tamamladıkları, problem çözme ön koşul becerilerinin okuduğunu anlama becerilerine dayalı olarak istenilen düzeyde olduğu tespit edilmiştir. Şekil 9'da K1'in uygun "stratejinin belirlenmesi" ve "değerlendirme/kontrol" aşamalarına yönelik verdiği cevabı ve araştırmacı ile diyalogları bu durumu en iyi şekilde temsil etmektedir.

K1:(Sesli şekilde okur). Problemin çözümü için seçtiğiniz işlemleri sözlü olarak ifade ediniz.

K1: Öğretmenim ilk başta 32 tane elma ă̆acı var (sessizce düşünür). 32 ile 32'yi toplayacă̆ız.

A1: Toplayınca neyi bulmuşoluyorsun?

K1: Elma ă̆actnı.

A1: Emin misin?

K1: Öğretmenim kiraz ağacı (biraz düşünür). Öğretmenim ikisini de bulmuş oluyorum.

K1:(Sesli şekilde okur) Problemi farkh şekilde çözebilir misin? Düşüncelerinizi sözlü olarak ifade ediniz.

A1: Problemi farklı şekilde çözebilir miydin?

K1: Öğretmenim bunu yukarı yazardım (çarpma işlemini gösterir). 2'yi, 64'ü aşă̆ıya yazardım.

A1: Emin misin? Farklı bir şekilde problemi çözebilir miydin?

K1: Himm, evet...

A1: Başka bir işlem yaparak sonuca ulaşabilir miydin?

K1:Öğretmenim bölme yapacă̆ız diyeceğim ama hep 0 çıkıyor. 


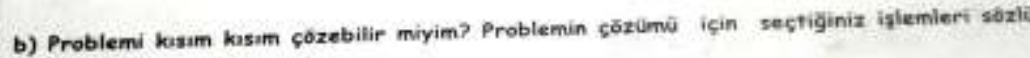
olarak ifade ediniz

OHUZ

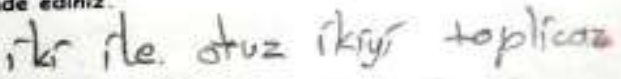

Şekil 9. K1'in Stratejinin Belirlenmesi Aşamasına İlişkin Cevabı

Araştırma kapsamında yukarıda verilen K1 öğrencisinin "stratejinin belirlenmesi" aşamasına ilişkin cevabının incelendiği Şekil 9 ve araştırmacı ile arasında geçen diyaloglar birlikte değerlendirildiğinde, çözüm için doğru stratejiyi belirlediği ancak stratejinin seçilme nedenini hatalı açılayıp cevap kâğıdını eksik yanıtladığı tespit edilmiştir. Şekil 10'da okuduğunu anlama becerisi orta düzey olan O1 kodlu öğrencinin "problemi anlama" aşamasına yönelik cevabı ve araştırmacı ile diyalogları verilmiştir.

A1: Ecrin ve dedesi ile ilgili problemde ne tür bilgiler verilmiş?

O1: (Yazarken sesli şekilde ifade eder). Dedesinin .....(düşünür). 32 tane elma ă̆acı varmış.

A1: 32 elma ă̆acı varmış. Öyle mi?

O1:Evet. Ve iki katıda kiraz ă̆acı varmış.

A1:Bizden istenen tam olarak nedir?

O1: Toplam ă̆aç sayısını bulmamızı istiyor.

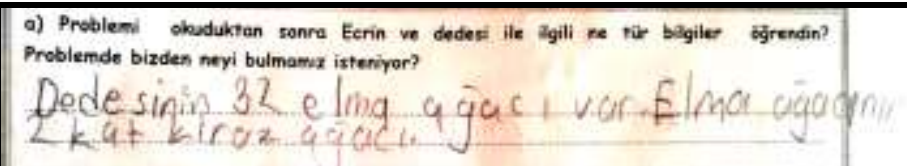

Şekil 10. O1 Kodlu Öğrencinin Problemi Anlama Aşamasına Ilişkin Cevabı

Şekil 10 incelendiğinde, O1'in problemi anlama aşamasında verileni doğru şekilde yazdığı ancak istenileni araştırmacı ile yapılan diyalogda ifade etmesine rağmen çalışma kâğıdına yazmadığı görülmektedir. O1 kodlu katılımcının çözüm için plan yapma ve planı uygulama aşamasına yönelik araştırmacı ile diyalogları ve cevabı Şekil 11'de verilmiştir.

O1:(Sesli şekilde okur). Problemin çözümü için seçtiğiniz işlemleri sözlü olarak ifade ediniz.

O1: A ğaçlarm kaç tane olduğunu bulacağız. 32 ile 2'yi çarpacă̆ız. (ileri ritmik sayar) İki dört. İki ile üçü çarparsak altı. Cevap 64.

A1: Peki 64 ile neyi bulmuş oluyorsun? 
O1: Kiraz ağacının sayısını.

A1: Neden iki ile çarpmayı seçtin?

O1: Soruda elma ă̆acının iki katı daha kiraz ă̆acı varmış dedenin. Ben kirazı 64 buldum. Şimdi 64 ile 32'yi toplayacağım. 4 ile 2'yi toplayınca 6.6 ile 3'ü toplayınca 9. Cevap 96.

A1: Neden toplama işlemi yapmayı seçtin?

O1: A ğaçların hepsini bulmamızı istiyordu. Topladım.

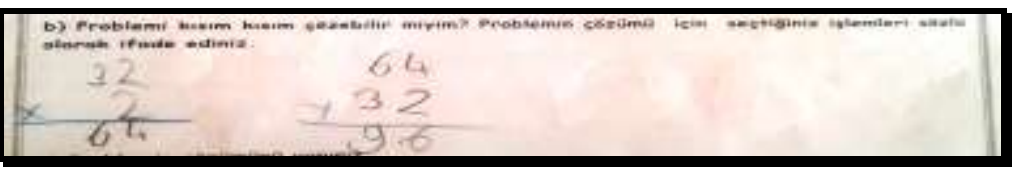

Şekil 11. O1 Kodlu Öğrencinin Uygulama Aşamasına İlişkin Cevabı

Yukarıda yer verilen Şekil 11 ve öğrencinin araştırmacı ile arasında geçen diyalog incelendiğinde, O1'in problemin çözümü için seçtiği işlemlerin nedenini doğru şekilde açıkladığı ve sonuca ulaştığ1 görülmektedir. Bu doğrultuda, okuma becerisi orta düzey olan O1'in işlemsel bilgi gerektiren "uygulama" aşamasında sorun yaşamadığı söylenebilir. Tablo 6'da öğrencilerin P6 için "uygulama" aşamasına yönelik yaşadığı güçlükler ve cevaplardan elde edilen bulgular verilmiştir.

Tablo 6. P6'nın Çözüm Aşamasına Yönelik Cevaplardan Ulaşılan Bulgular

\begin{tabular}{lllll}
\hline Problemi Anlama & & Str.nin Belirlenmesi & Uygulama & Değerendirme \\
\hline Hiç Anlamayan & Eksik Anl. & & & \\
& K1 & O2 & O2 & K1 \\
& K2 & K2 & K2 & K2 \\
\hline
\end{tabular}

Tablo 6 incelendiğinde, okuduğunu anlama becerisi orta düzey olan $\mathrm{O} 2$ kodlu öğrencinin "problemi anlama" basamağında verilen ve istenileni doğru şekilde açıklamasına ve araştırmacı tarafından problemin çözümüne ilişkin sorulan sorulara ileri ritmik saymayı kullanarak doğru cevabı vermesine rağmen "stratejinin belirlenmesi ve uygulanması" aşamalarında işlem hatası yaptığı ancak doğru cevaba ulaştığı görülmektedir. Öğrencinin probleme "stratejinin belirlenmesi" aşamasında zihninden işlem yaparak bulduğu sonucu hangi stratejiyi kullanarak bulacağını hatalı ifade etmesi ve problemin çözümü için kullandığı işlemlerde hata yapması; problem dilini doğ- 
ru anlayarak matematiksel işlem becerilerinin geliştirilmeye ihtiyacı olduğunu göstermektedir. Okuma düzeyi düşük olan K2 kodlu öğrencinin problemin çözümünün tüm aşamalarında sorun yaşadığı, K1 kodlu öğrenci ise "problemi anlama" aşamasında verilen ve isteneni ifade ederken soruyu olduğu gibi yazmanın problemi doğru ifade etmek anlamına geldiğini düşünmekte ve araştırmacı tarafından yönlendirici sorular ve problemde geçen anahtar kelimelerle "uygulama" aşamasında çözüme gittiği ve "değerlendirme/kontrol" aşamasında ise herhangi bir işlem yapmadığı görülmektedir. Okuduğunu anlama düzeyi yüksek olan Y1, Y2 ve orta seviye olan O1 sorunun aşamalarını başarılı şekilde gerçekleştirmişlerdir.

Şekil 12'de okuduğunu anlama becerisi orta düzey olan O2'nin "stratejinin belirlenmesi" ve "uygulama" aşamasına yönelik verdiği cevabı ve diyalogları yer almaktadır.

O2:(Sesli şekilde okur). Problemin çözümü için seçtiğiniz işlemleri sözlü olarak ifade ediniz.

O2: Çarpma. On dört, yirmi sekiz, otuz iki. (düşünür) 56. Tamam bu doğru.

A1: Az önce hangi işlemle yaptın?

O2: Çarpma

A1: Çarpma işlemini seçmenin nedeni nedir?

O2: Şey. Dört çarpı on kırk. Kırkdan saymaya başladım.Dört, sekiz, on iki ,on altı. On altryla bunu topladım sonra o sonucu (56'yı gösterir) buldum.

O2:(Sesli şekilde okur). Problemin çözümünü yapını.

A1: Duygunun kaç poşete ihtiyacı olduğunu nasıl bulabiliriz?

O2: Bunu da bölmeyle bulabiliriz.

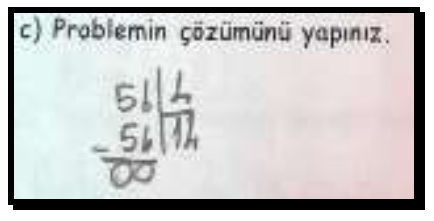

Şekil 12. Okuma Becerisi Orta Düzeydeki O2'nin Uygulama Aşaması için Cevabı

Yukarıda yer verilen şekil incelendiğinde, $\mathrm{O} 2$ 'nin problemin çözümü için "stratejinin belirlenmesi" aşamasında ileri ritmik sayma kullanarak ve zihinden işlemler yaparak sözlü şekilde sonucu söylediği ve işlemsel bilgi 
gerektiren "uygulama" aşamasında ise bölme işlemini hatalı yaptığı ancak doğru cevaba ulaştı̆̆1 görülmektedir. Bu durum, öğrencilerin problem çözme esnasında ihtiyaç duydukları bilgileri organize etme ve etkin kullanmada güçlük çekebileceklerine ve hatalı sonuçlar sergileyebileceklerine de işaret edebilir. Düşük okuma becerisine sahip olan K1'in "değerlendirme/kontrol" aşamasına cevabı ve araştırmacı ile diyalogları verilmiştir.

K1:(Sesli şekilde okur)Problemin çözümü için yapılan işlemleri kontrol edin ve sözlü olarak ifade edin.

A1: Yaptı̆̆ın işlemin doğrulunu nasıl kontrol edebilirsin?

K1: Öğretmenim şimdi elli altıyı dörde böldük. Beşin için dört bir defa var. Biri yazdık. Dört kere bir dört. Öğretmenim beşten dört çıkı bir kaldı. Biri aşă̆ıya indireceğiz. On altının içinde dört, dört kere dört on altı. On altıyı yazdık. Sonuç çift sıfır.

A1:Peki.Bölmede, işlemin doğrulunu farklı şekilde kontrol edebilir misin?

K1: Hayır öğretmenim.

Yapılan incelemelerde, $\mathrm{K} 1$ 'in problemin nasıl doğrulanacağı hakkında bir fikri olmadığı için çalışma kağıdını boş bıraktığı ve okuduğunu anlama becerisi düşük olan K1'in "değerlendirme/kontrol" aşamasında düşük bir performans gösterdiği söylenebilir.

\section{Tartışma ve Sonuç}

Bu çalışmada, ilkokul üçüncü sınıf öğrencilerinin okuma becerilerine göre problem çözme başarıları ile problem çözme sürecinde karşılaştıkları güçlüklerin incelenmesi amaçlanmıştı. Bu amaçla, bu kısımda farklı düzeyde okuma becerisine sahip olan öğrencilerin araştırma kapsamında kendilerine uygulanan matematik problem çözme testi ile yapılan mülakatlar sonucunda elde edilen bulgulardan hareketle ulaşılan sonuçlara yer verilmiştir.

Çalışma kapsamında ulaşılan bulguların yer aldığı tablolar ışığında, okuduğunu anlama düzeyi düşük olan öğrencilerin problem çözme basamaklarının dördünde de güçlük çektikleri tespit edilmiş ve hem okuduğunu anlama hem de problem çözme becerilerinin geliştirilmeye ihtiyacı olduğu anlaşılmıştır. Bununla birlikte, okuduğunu anlama düzeyleri yüksek olan öğrenciler ile orta olan öğrencilerden birinin problem çözmede genelde başarılı olduğu görülmüştür. Orta düzeyde okuma becerisine sahip olan bir öğrencinin ise bazı problemlerde ve özellikle de bazı prob- 
lem aşamalarında zorlukları olduğu anlaşılmıştır. Bu kapsamda, problemi anlama basamağında sorun yaşayan öğrencilerin okuduğunu anlama düzeyine bağlı olarak farklı nedenlerle sorunlar yaşadıkları belirlenmiştir.

Genel olarak, okuma becerisi düşük düzeyde olan öğrencilerin "problemi anlama" aşamasında çoğunlukla zorlanmışlardır ancak orta ve yüksek düzeyde okuma becerisine sahip olan birer öğrencinin de yalnızca bazı problemlerde problem çözme aşamalarından "problemi anlama" aşamasında probleme uygun şekil çizmede sorun yaşamaları nedeni ile zorlukları bulunduğu belirlenmiştir. Bu kapsamda, diğer orta düzeyde okuma

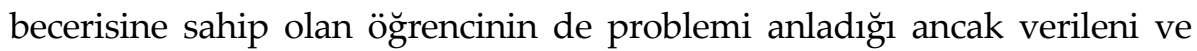
istenileni yeterince ayırt edemediği ve eksik yazdığı anlaşılmıştır. Ayrıca, okuduğunu anlama becerisi düşük olan öğrencilerin problem metnini kendi cümleleri ile ifade etme, problemde yer alan eksik ve fazla bilgi içeren verilerin çözüm için gerekli olup olmadığı konusunda akıl yürütmede zorluk çektikleri, verileni ve istenileni tespit edemediklerinden dolayı problem çözme sürecinde sorun yaşadıkları ve burada çoğunlukla problem ifadesinin aynısını yazdıkları belirlenmiştir. Ulaşılan bu sonuçlar Gökkurt-Özdemir vd. (2018), Ekici ve Demir (2018) ve Arsal (2009) tarafından yapılan çalışmalarının sonuçları ile benzerlik göstermektedir. Bu araştırmalardan Gökkurt-Özdemir vd. (2018) tarafından yapılan araştırmada ilköğretim öğrencilerinin problem cümlesi içerisindeki eksik ve fazla bilgiyi belirlemekte zorlanmaları ve verilerin problem çözümünde kullanılması gerektiği üzerine akıl yürütmekte güçlük çektikleri belirtilirken, Ekici ve Demir (2018) tarafından yapılan çalışmada ilkokul öğrencilerinin okuduklarını ifade etme ve anlamada zorluk çektikleri ve bu nedenle çözümde başarısız oldukları açıklanmıştır. Benzer şekilde, Arsal (2009) tarafından yapılan çalışmada da problem çözme aşamalarının kullanımının problem çözümünü etkilediği de ifade edilmiştir. Bu araştırmada, okuduğunu anlama düzeyi orta ve yüksek olan öğrencilerin bazılarının da probleme uygun şekil çizememekle birlikte problemin diğer aşamalarında başarılı oldukları görülmüştür ki, bu durum matematik dersindeki etkinliklerde öğretmenlerin problemi anlamaya yönelik okuduğunu anlama stratejilerine (soru sorma, okuma, özetleme stratejisi vb.) yer vermesinin önemli olduğuna işaret etmektedir.

Çalışmada yer alan problemlerde "stratejinin belirlenmesi" ve "uygulama" aşamalarında sorun yaşayan katılımcilardan okuduğunu anlama 
düzeyi düşük olan öğrencilerin problemin çözümü ile ilgili ilgisiz cevaplar vermeleri, seçilen işlemi ifade ederken mantıklı olmayan açılamalar yapmaları, problemi tam olarak anlamadan işlemi açıklayarak problemi çözmeyi istemeleri, seçilen işlemin nedenini tam olarak ifade edememelerinin başarısızlığa neden olduğuna işaret etmektedir. Ayrıca, benzer problemlerin çözüm yöntemlerini ezberleyerek işlemler yapmaları, strateji ve işlem seçerken problemdeki anahtar kelimelere odaklanmaları, mevcut işlemsel bilgileri stratejinin uygulanması basamağında sorunun çözümüne aktaramamaları, işlemsel bilgi ve matematik kavramları arasındaki ilişkiyi kuramayarak kullanılacak işleme karar verememelerinin de öğrencilerin yine problem çözmede başarısız olmalarına neden olduğu yapılan görüşmelerden anlaşılmıştır. Okuduğunu anlama becerisi orta düzey olan katılımcilardan "problemi anlama" aşamasında verilen ve isteneni tam olarak ifade edemeyen öğrencilerin, "uygulama" aşamasında işlem hataları yaptığ 1 ve dört işlemle ilgili bilgi ve becerilerini tam olarak soru çözümünde uygulayamadıkları buna karşın okuduğu anlama düzeyi yüksek olan öğrencilerin "stratejinin belirlenmesi" ve "uygulama" aşamalarında sorun yaşamadıkları belirlenmiştir. Bu durum, okuduğunu anlama becerisinin ve öğrencinin sahip olduğu temel matematik bilgilerinin bireyin "problemi anlama" ve "stratejinin belirlenmesi" aşamaları üzerinde etkili olduğunu göstermektedir (Çavuşoğlu, 2010). Okuduğunu anlama becerileri ve "problemi anlama/ifade etme" aşamasında performansları daha yüksek olan öğrencilerin buna paralel olarak problem çözme aşamalarında uygun stratejinin seçilmesi ve stratejinin uygulanması basamaklarında da başarı düzeylerinin arttığı da ulaşlan bulgulardan anlaşılmaktadır. Araştırma kapsamında ulaşılan bu sonuçlar Gökkurt vd.(2015) tarafından yapılan çalışmanın sonucunda ulaşılan ilköğretim öğrencilerinin "problemi anlama", "stratejinin belirlenmesi", "uygulama" ve "değerlendirme/kontrol" aşamaları kapsamında problem kurmada yeterli performansı göstermedikleri buna karşın "stratejinin belirlenmesi" aşamasında başarılı olan öğrencilerin, "uygulama" aşamasında da başarılı oldukları sonucunu destekler niteliktedir. Bu araştırmada da çözüm uygun stratejiyi belirleyen ve okuduğunu anlama düzeyi yüksek ve orta olan öğrenciler "uygulama" aşamasında aynı performansı göstermektedirler. Problem çözerken okuduğunu anlama aşamasında problemi özetleyerek somut materyallerle ifade eden, anlamını bilmediği kelimeleri bulan, problemi farklı ifade etme 
durumunda ise verilen ve istenileni doğru şekilde yazan, şekil ve şema stratejilerini kullanan öğrencilerin problem çözümünde başarılı oldukları bilinmektedir (Arsal, 2009). Uçar (2010) ve Polat (2012) tarafindan yapılan çalışmalarda, öğrencilerin Türkçe becerileri/okuduğunu anlama becerisi ile problem çözme başarısı arasında olumlu ilişkiler açıklanmıştır ki, bu durum da bu araştırmanın sonuçlarını desteklemektedir. Ayrıca, Polat (2012) okuduğunu anlamanın problem çözmede tek başına etken olmad1ğını, problemi anlamayı zorlaştıran kelimelerin, dikkatsizliğin, işlem hatalarının da problem çözümünü olumsuz şekilde etkilediğini belirtmiştir. Bu durum da yine, bu araştırma kapsamında ulaşılan okuduğunu anlama becerisi orta düzey olan öğrencilerin "uygulama" aşamasında işlemsel bilginin aktarılamamasından kaynaklı hata yaptıkları görüşünü destekler niteliktedir. Bu nedenle, matematik dersinde ilkokuldan başlanarak problem çözme çalışmaları içerisinde öğrencilerin okuma ve okuduğunu kendi anlatımlarıyla zenginleştirerek matematiksel hatalarını fark edebilecekleri bir ortamda problem kurma çalışmalarının bütünleştirilerek gerçekleştirilmesi, problem çözme ve kurma başarılarını yükselmesinde etkili olabilir.

\section{Öneriler}

Bu araştırmada, ilkokul üçüncü sınıf öğrencilerinin okuma becerilerine bağlı olarak, okuduğunu anlama seviyesi düşük olan öğrencilerin "problemi anlama" aşamasında verilen ve istenileni yazma, şekil çizme, problem ifadesinin aynısını yazma, problemde fazla ve eksik bilgi içeren verileri ayırmakta sorun yaşadıkları ve yetersiz oldukları belirlenmiştir. Bu nedenle, matematik derslerinde yer alan problem çözme etkinlerinde öğretmenlerin sadece öğrencilerin problemi çözerek doğru sonuca ulaşmalarına odaklanmak yerine öncelikle sınıf içerisinde yer alan her öğrencinin problemi anlamalarına yoğunlaşmaları ve bu aşamada rehberlik yaparak sesli okuma, okuduğunu sınıf içerisinde ifade etme, öğrencilere problemle ile ilgili sorular sorarak açıklamalarına fırsat verme, problem içerisindeki verilen ve istenileni sorgulama ve muhakeme yapmalarına yönelik etkinliklere ağırlık vermeleri ve öğrencilerin aktif katılımını desteklemeleri, problem çözme başarılarının artması açısından faydalı olabilir.

Problem çözme sürecinde "stratejinin belirlenmesi" ve "uygulama" aşamasında okuduğunu anlama düzeyi düşük olan öğrencilerin seçilen 
işlemin nedenini tam olarak ifade edememeleri, işlemsel bilgi ve matematik kavramları arasındaki ilişkiyi kuramayarak kullanılacak işleme karar verememeleri ve işlem hataları yapmaları; matematik dersi içerisinde okuduğunu anlamaya yönelik stratejilerin kullanımının yanında işlem becerilerinin gelişmesi için problem çözme sürecinde öğrencilerin başar1larını arttıracak ve okuduğunu anlama beceri seviyelerini de göz önüne alarak bireysel gelişimlerini destekleyecek problem çözme eğitimine öncelik verilmesini önemli kılmaktadır. Problem çözme sürecinde "değerlendirme/kontrol" aşamasında benzer problemlerin yazılması ile ilgili bilgi eksikliği, kurulan problemdeki eksik ve fazla bilgiyi fark edememe, çözüme ulaşabilecek bir problemin kurulmaması sorunlarının azaltılmasına yönelik çalışmalar yapılabilir. Bu kapsamda, öğrencilerin ön bilgileri ile matematik işlem bilgisi arasında bağ kurabilecekleri, sınıf içerisinde aktif katılımlı problem çözme süreci içerisinde çözümün kontrolü ve problem kurma çalışmalarını gerçekleştirilebilecekleri, matematiğin günlük hayattaki yerini fark edebilecekleri problem çözme çalışmalarının yapılması da öğrencilerin başarılarına katkı sağlayabilir.

Yapılacak olan farklı çalışmalarda farklı sınıf düzeylerindeki öğrencilerin okuduğunu anlama ve problem çözme başarıları ve problem çözme sürecini etkileyen davranışları ve yaşanılan güçlükler incelenebilir. İlgili alan yazın incelendiğinde, yapılan çalışmaların genellikle ortaokul, lise ve üst eğitim grubundaki öğrenciler (Çiftçi ve Temizyürek 2008; Göktaş, 2010; Semizoğlu, 2013) ile gerçekleştirildiği görülmektedir. Bu nedenle, benzer çalışmalar farklı örneklem grupları seçilerek yürütülebilir. Çalışmada elde edilen sonuçlar ışığında, okuduğunu anlama becerilerine bağlı olarak öğrencilerin problem çözme başarılarını arttıracak ve problem çözme becerilerini geliştirecek tarzda eğitimler verilerek ve bu eğitimlerin seçilen öğrenciler üzerindeki etkileri incelenerek literatüre katkı sağlanabilir. 


\section{EXTENDED ABSTRACT}

\section{The Problem-Solving Achievements and the Difficulties in Solving Process of Third Grade Stu- dents according to Reading Skills}

Dilek Sezgin Memnun - Nezaket İlksen Kanbur Bursa Uludağ University, Ministry of National Education

One of the objectives of education is to train the individual who have the necessary skills can acquire to produce solutions to the challenges they will face in the future. Because of that, it is accepted that improving students reading comprehension skills in primary school contributes to their academic achievement in different subjects and training process where reading habits earned of these students effect future lives. Science and technology affect the individuals' lives and the need for qualified access to the right information as a result of this (Ersoy, 1997). One of the important rules of the individuals to get right and enough knowledge is reading and ability to read and understand correctly. The other aim of education is to train individuals equipped and producing contemporary solutions to the problems (Özsoy, 2007). In addition, it is necessary for students to read and understand the problem correctly in order to be successful in problem solving stages in mathematics course. There are different studies explain the effect of the reading skills on academic success and problem-solving process in mathematics course (Albayrak \& Erkal, 2003; Çavuşoğlu, 2010). Besides, the success of students in problem solving process requires to read and understand of the problem properly (Sert, 2010; Şengül and Yalçın, 2004). Because of that, it was aimed to examine the problem-solving success of primary school third grade students according to their reading skills and their difficulties in problem solving process.

The data were obtained through the reading comprehension text consisting of a total of 12 questions for the reading skills of the participants and six open-ended questions for mathematics problem solving skills. In 
the study, a case study (a qualitative one) was used because it was aimed to determine the difficulties faced by the students in problem solving stages and to investigate the behaviors in problem solving process according to their level of reading comprehension skills. With this aim, the interviews were conducted with the participant students consists of six third grade students, who represent high-middle-low group depending on the level of reading comprehension, selected from a total of ninetythird grade students in the province of Kocaeli in 2018-2019 academic year. The obtained data were analyzed using descriptive statistics.

According to the results of the study, it was understood that the students who have low level of reading comprehension skills had problems in all stages of problem solving while the students with high level of reading comprehension skill were successful in all problem-solving stages. Besides, these students had problems in controlling the solution and problem formation stages in general according to the level of reading comprehension. Additionally, it was understood that the success levels of the students, who have high level reading comprehension skills, in determining the appropriate strategy and applying this strategy.

In this study, depending on the reading skills of the third grade students of primary school, it was determined that the students with low reading comprehension had problems and were insufficient in separating the data given in the "understanding the problem" phase, writing the desired, drawing the same expression, writing the same problem statement, and containing more and less information in the problem. For this reason, instead of focusing only on the problem solving of the students by solving the problem in the problem solving activities in mathematics lessons, first of all, the students in the classroom concentrate on understanding the problem and by reading at this stage, reading aloud, expressing what they read in the classroom, asking the students questions about the problem. It may be beneficial for them to increase their success in problem solving by giving them an opportunity to explain their explanations, to focus on the activities that are given in the problem and to question what is desired, and to support students' active participation. The research results were similar with different other studies which held on by Gökkurt-Özdemir vd. (2018), Ekici and Demir (2018), Uçar (2010), Polat (2012) and Arsal (2009). In future studies, difficulties of 
different grade level students in reading comprehension and problemsolving stages can be examined. In addition, according to the level of reading comprehension of the students, problem-solving skills and achievements can be arranged to increase training. Performing problem solving studies in which students can connect their prior knowledge with mathematical knowledge, control the solution in problem solving process with active participation in the classroom, and realize the place of mathematics in daily life can also contribute to the success of students. In the light of the results obtained in the study, depending on their reading comprehension skills, they can contribute to the literature by providing trainings that will increase the problem solving success of the students and improve their problem solving skills and by examining the effects of these trainings on the selected students.

\section{Kaynakça / References}

Albayrak, M. ve Erkal, M. (2003). Başarıya giden yolda ifade ve beceri derslerinin (Türkçe-matematik) birlikteliği. Millî Eğitim Dergisi, 158, 150-155.

Arsal, Z. (2009). Problem çözme stratejilerinin problem çözme basarısını yordama gücü. Abant İzzet Baysal Üniversitesi Eğitim Fakültesi Dergisi, 9(1), 103- 113.

_Aydın-Akay, A. (2004). Illköğretim 2. smıföğrencilerinin okuduğunu anlama becerilerinin matematik problemlerini çözme başarısına etkisi. Yayımlanmamış yüksek lisans tezi, Marmara Üniversitesi Eğitim Bilimleri Enstitüsü, İstanbul.

Baştuğ, M. ve Keskin, H.K. (2012). Akıcı okuma becerileri ile anlama düzeyleri (Basit ve çıkarımsal) arasındaki ilişki. Ahi Evran Üniversitesi Kırşehir Ĕğitim Fakültesi Dergisi, 13(3), 227-244.

Bayrakçı, R. (2004). Ilköğretim 4. Simff Türkçe dersinde uygulanan okuduğunu anlama ve problem çözüm stratejilerinin öğrenci başarılarına etkisi. Yayımlanmamış yüksek lisans tezi, Selçuk Üniversitesi Sosyal Bilimler Enstitüsü, Konya.

Birbiri, D. (2014). PISA 2003 ve PISA 2012 sınav sonuçlarının problem çözme becerilerine yönelik değişkenlerinin Türkiye açısından incelenmesi. Yayımlanmamış yüksek lisans tezi, Atatürk Üniversitesi Eğitim bilimleri enstitüsü, Erzurum. 
Boz, İ. (2018). İlkokul 4. sınıf öğrencilerinin okuduğunu anlama düzeyi ile matematik problemlerini çözme başarısı arasındaki ilişkinin incelenmesi. Insan ve Sosyal Bilimler Dergisi, 1(1), 40-53.

Büyüköztürk, Ş., Çakmak, E.K., Akgün, Ö.E., Karadeniz, Ş., ve Demirel, F. (2012). Bilimsel araştırma yöntemleri (2. bs.). Ankara: Pegem Akademi.

Cantürk-Günhan, B., ve Başer, N. (2009). Probleme dayalı öğrenmenin öğrencilerin eleştirel düşünme becerilerine etkisi. Türk Ĕ̆itim Bilimleri Dergisi, $7(2), 451-482$.

Çavuşoğlu, E. (2010). İlköğretim beşinci sinıf öğrencilerinin okuduğunu anlama düzeyi ile matematik problemlerini çäzme başarısı arasındaki ilişkinin incelenmesi. Yayımlanmamış yüksek lisans tezi, Gazi Üniversitesi Eğitim Bilimleri Enstitüsü, Ankara.

Çelebioğlu, B. (2009). Illköğretim birinci sını öğrencilerinin problem çözme stratejilerini kullanabilme düzeyleri. Yayımlanmamış yüksek lisans tezi, Uludağ Üniversitesi Eğitim Bilimleri Enstitüsü, Bursa.

Çelik, D. ve Güler, M. (2013). İlköğretim 6. sınıf öğrencilerinin gerçek yaşam problemlerini çözme becerilerinin incelenmesi. Dicle Üniversitesi Ziya Gökalp Ĕ̆itim Fakültesi Dergisi, 20, 180- 195.

Çenberci, S. (2018). The investigation of the creative thinking tendency of perspective mathematics teachers in terms of different variables. Journal of Education and Training Studies, 6(9), 78-85.

Çepni, S. (2012). Araştırma ve proje çalışmalarnna girişs (6.bs.). Trabzon: Celepler Matbaacilı.

Çiftçi, Ö. ve Temizyürek, F. (2008). İlköğretim 5. sınıf öğrencilerinin okuduğunu anlama becerilerinin ölçülmesi. Mustafa Kemal Üniversitesi Sosyal Bilimler Enstitüsü Dergisi, 5(9), 109-129.

Çiftçi, C., Sezgin-Memnun, D., ve Aydın, B. (2018). Ortaokul öğrencilerinin okuma becerileri ile matematik problemlerini çözme başarıları arasındaki ilişkiler. The Journal of Academic Social Science Studies, 73, 531-544.

Çolak, E.D. (2017). Örnek olay inceleme yönteminin 8. sinıf Türkçe dersi okuma ve yazma başarısı ile problem çözme becerisine etkisi. Yayımlanmamış yüksek lisans tezi, Giresun Üniversitesi Sosyal Bilimler Enstitüsü, Giresun.

Ekici, B. ve Demir, M.K. (2018). İlkokul 4. sınıf öğrencilerinin dört işlem problemlerini çözerken yaptıkları matematiksel hatalar. Eğitimde Kuram ve Uygulama, 14(1), 61-80.

Ersoy, Y. (1997). Okullarda matematik eğitimi: Matematikte okuryazarlık. Hacettepe Üniversitesi Eğitim Fakültesi Dergisi, 13(13), 115-120. 
Goldin, G.A. (1998). Observing mathematical problem solving through taskbased interviews. (Ed. A.A. Tempo). Qualitative Research Methods In Mathematics Education, NCTM.

Gökkurt, B., Örnek, T., Hayat, F., ve Soylu, Y. (2015). Öğrencilerin problem çözme ve problem kurma becerilerinin değerlendirilmesi. Bartın Üniversitesi Ĕ̆itim Fakültesi Dergisi, 4(2), 751-774.

Gökkurt-Özdemir, B., Usta, N., Demir, Ö., ve Minisker, M. (2018). Sekizinci sinıf öğrencilerinin problem çözme sürecinde sözel problemleri sorgulama becerilerinin incelenmesi. Erzincan Üniversitesi Eğitim Fakültesi Dergisi, 20(2), 366-386.

Göktaş, Ö. (2010). Okuduğunu anlama becerisinin ilköğretim ikinci kademe matematik dersindeki akademik başarıya etkisi. Yayımlanmamış yüksek lisans tezi, İnönü Üniversitesi Eğitim Bilimleri Enstitüsü, Malatya.

Gündüz, Ş. ve Odabaşı, F. (2004). Bilgi çağında öğretmen adaylarının eğitiminde öğretim teknolojileri ve materyal geliştirme dersinin önemi. TOJET, $3(1), 43-48$.

Güven, M. ve Kürüm, D. (2008). Öğretmen adaylarının öğrenme stilleri ile eleştirel düşünme eğilimleri arasındaki ilişki:Anadolu Üniversitesi Eğitim Fakültesi öğrencileri üzerinde bir araştırma. Illköğretim Online, 7(1), 5370.

Hamurcu, C.G. (2016). İlköğretim 7. sinnf Türkçe dersinde otantik öğrenmenin öğrencilerin problem çözme ve okuduğunu anlama becerileri ile derse ilişkin tutumlarına etkisi. Yayımlanmamış doktora tezi, İnönü Üniversitesi Eğitim Bilimleri Enstitüsü, Malatya.

Ilgın, H. (2010). Ilköğretim ikinci sımı öğrencilerinin problem çz̈zme becerilerinin metinlerle geliştirilmesi. Yayımlanmamış yüksek lisans tezi, Mehmet Akif Ersoy Üniversitesi Sosyal Bilimler Enstitüsü, Buldur.

Işık, C. ve Kar, T. (2011). İlköğretim 6, 7 ve 8. sınıf öğrencilerinin sayı algılama ve rutin olmayan problem çözme becerilerinin incelenmesi. Ahi Evran Üniversitesi Ĕ̆itim Fakültesi Dergisi, 12(1), 57-72.

İlhan, C. (2014). SQ3R akıcı okuma stratejisinin ilkokul 4. sinıf öğrencilerinin fen ve teknoloji dersi akademik başarları, problem çözme becerileri ve fen tutumlarına etkisi. Yayımlanmamış yüksek lisans tezi, Ahi Evran Üniversitesi Sosyal Bilimler Enstitüsü, Kırşehir. 
Jordan, N. C., Hanich, L. B. ve Kaplan, D. (2003). A Longitudinal Study of Mathematical Competencies in Children With Specific Mathematics Difficulties Versus Children With Comorbid Mathematics and Reading Difficulties. Child Development, 74, 834-850.

Kalayc1, S. ve Hürriyetoğlu, N. (2018). İlkokul 1. sınıf öğrencilerine matematik problemi çözme becerisinin kazandırılması: Pipet etkinliği. Eğitim Kuram ve Uygulama Araştırmaları Dergisi, 2(4), 31-44.

Kaplan, A., Duran, M., ve Baş, G. (2016). Ortaokul Öğrencilerinin matematiksel üstbiliş farkındalıkları ile problem çözme beceri algıları arasındaki ilişkinin yapısal eşitlik modeliyle incelenmesi. İnönü Üniversitesi Eğitim Fakültesi Dergisi, 17 (1), 1-16.

Karadedeli, İ. (2018). İlkokul 4. sınıf öğrencilerinin eleştirel okuma ve problem çözme becerilerinin çeşitli değişkenlere göre incelenmesi: Uşak ili örneği. Yayımlanmamış yüksek lisans tezi, Uşak Üniversitesi Sosyal Bilimler Enstitüsü, Uşak.

Karasar, N. (2005). Bilimsel araştırma yöntemleri. Ankara: Nobel Yayınları.

Milli Eğitim Bakanlığı (MEB) (2018). Illkokul ve Ortaokul Matematik Dersi (1, 2, 3, 4, 5, 6, 7 ve 8. Sinıflar) Ö̆gretim Programı. Ankara: MEB.

Özbilgin, E. (2018). Sekizinci sınıf öğrencilerinin üstbilişsel okuma becerileri üzerine bir araştırma. Yayımlanmamış yüksek lisans tezi, İstanbul Üniversitesi Eğitim Bilimleri Enstitüsü, İstanbul.

Özcan, Y. (2016). Ortaokul öğrencilerinin okuduğunu anlama becerisi ile matematik dersinde problem çözme başarısı arasındaki ilişki. Yayımlanmamış yüksek lisans tezi, Fırat Üniversitesi Eğitim Bilimleri Enstitüsü, Elazı̆̆.

Özçelik, E.G. (2011). Okuduğunu anlama becerisinin başarıya etkisi. Yayımlanmamış yüksek lisans tezi, Hacettepe Üniversitesi Sosyal Bilimler Enstitüsü, Ankara.

Özsoy, G. (2006). Problem çözme ve üstbiliş. Ulusal Sinıf Öğretmenliğgi Kongresi'nde sunulmuş bildiri, Gazi Üniversitesi, 14-16 Nisan, Ankara, Türkiye.

Özsoy, G. (2007). İlköğretim 5. sınıfta üstbiliş stratejileri öğretiminin problem çözme becerisine etkisi. Yayımlanmamış doktora tezi, Gazi Üniversitesi Eğitim Bilimleri Enstitüsü, Ankara.

Paris, H. (2017). İlkokul öğrencilerinin akıcı okuma becerilerinin çeşitli değişkenlere göre incelenmesi. Yayımlanmamış yüksek lisans tezi, Erciyes Üniversitesi Eğitim Bilimleri Enstitüsü, Kayseri. 
Polat, G.B. (2012). İlköğretim 7. ve 8. sınıflarda Türkçe-matematik birlikteliğinin öğrencilerin problem çözme becerisine etkisi. Yayımlanmamış yüksek lisans tezi, Dokuz Eylül Üniversitesi Eğitim Bilimleri Enstitüsü, İzmir.

Polya, G. (1957). Nasıl çözmeli? çev. Feryal Halatçı, İstanbul: Sistem Yayıncılık.

Semizoğlu, R. (2013). İlköğretim 5. sinıf öğrencilerinin okuduğunu anlama ve görsel okuma düzeyi ile problem kurma becerisi arasındaki ilişkinin incelenmesi. Yayımlanmamış yüksek lisans tezi, Gazi Üniversitesi Eğitim Bilimleri Enstitüsü, Ankara.

Serin, O., Serin, B.N., ve Saygıll, G. (2010). İlköğretim düzeyindeki çocuklar için problem çözme envanterinin (ÇPÇE) geliştirilmesi. Ilköğretim Online Dergisi, 9(2), 446-458.

Sert, A. (2010). İlköğretim altıncı sınıf öğrencilerinin okuduğunu anlama becerilerinin bazı değişkenler açısından incelenmesi. Yayımlanmamış yüksek lisans tezi, Selçuk Üniversitesi Eğitim Bilimleri Enstitüsü, Konya.

Soylu, Y. ve Soylu, C. (2006). Matematik derslerinde başarıya giden yolda problem çözmenin rolü. İnönü Üniversitesi Ĕ̆itim Fakültesi Dergisi, 7(11), 97111.

Şengül, M. ve Yalçın, S.K. (2004). Okuma ve anlama becerilerinin geliştirilmesine yönelik olarak hazırlanan bir model önerisi. Milli Ĕ̆itim Dergisi, 164.

TDK (2019). Türk Dil Киrumu sözlüğü. 21.04.2019 tarihinde http://www.tdk.gov.tr adresinden erişildi.

Tezgören, I. (2015). Sekizinci sınıf öğrencilerinin bilimsel okuryazarlık düzeyleri ile problem çözme becerileri arasındaki ilişkinin incelenmesi. Yayımlanmamış yüksek lisans tezi, Eskişehir Osmangazi Üniversitesi Eğitim Bilimleri Enstitüsü, Eskişehir.

Tuohimaa, P.M.V., Aunola, B., ve Nurmi, J. (2008). The association between mathematical word problems and reading comprehension. Educational Psychology, 28(4), 409-426.

Türnüklü, E.B. ve Yeşildere, S. (2014). Problem, problem çözme ve eleştirel düşünme. Gazi Üniversitesi Gazi Eğitim Fakültesi Dergisi, 25(3), 107-123.

Tüysüz, C. (2013). Üstün yetenekli öğrencilerin problem çözme becerisine yönelik üstbiliş düzeylerinin belirlenmesi. Mustafa Kemal Üniversitesi Sosyal Bilimler Enstitüsü Dergisi, 10(21), 157-166.

Uçar, C. (2010). Okuduğunu anlama becerisi ile gerçek hayat ve standart sözel problemleri çözme başarısı arasındaki ilişki. Yayımlanmamış yüksek lisans tezi, Abant İzzet Baysal Üniversitesi Sosyal Bilimler Enstitüsü, Bolu. 
Ulu, M., Tertemiz, N., ve Peker, M. (2016). Okuduğunu anlama ve problem çözme stratejileri eğitiminin ilköğretim 5. sınıf öğrencilerinin rutin olmayan problem çözme başarısına etkisi. Afyon Kocatepe Üniversitesi Sosyal Bilimler Dergisi, 18(2), 303-340.

Uzun, C. (2010). İlköğretim öğrencilerinin matematik dersi problem çözme başarılarının bazı demografik değişkenler ve okuduğunu anlama becerisi açısından incelenmesi. Yayınlanmamış yüksek lisans tezi, Uşak Üniversitesi Sosyal Bilimleri Enstitüsü, Uşak.

Yıldız, M. (2013). Okuma motivasyonu, akıcı okuma ve okuduğunu anlamanın ilköğretim beşinci sınıf öğrencilerinin akademik başarılarındaki rolü. Turkish Studies - International Periodical For The Languages, Literature and History of Turkish or Turkic, 8(4), 1461-1478.

Yıldırım, A. ve Şimsek, H. (2008). Sosyal bilimlerde nitel araştırma yöntemleri. (6.bs.). Ankara: Seçkin Yayıncilık.

Yin, R.K. (1984). Case study research: Design and methods. Beverly Hills, Calif: Sage Publication.

\section{Kaynakça Bilgisi / Citation Information}

Sezgin-Memnun, D. ve İlksen Kanbur, N. (2020). Üçüncü sınıf öğrencilerinin okuma becerilerine göre problem çözme başarıları ve çözüm sürecinde karşılaştıkları güçlükler. OPUS-Uluslararası Toplum Araştırmaları Dergisi, 15(22), 927-965. DOI: 10.26466/opus. 639152 